\title{
Experimentação e ressignificação de elementos composicionais do Clube da Esquina no processo de criação de dois arranjos vocais
}

Experimentation and reinterpretation of Clube da Esquina's compositional elements in the process of creating two vocal arrangements

Carlos Roberto Ferreira de Menezes Júnior ${ }^{1}$ Universidade Federal de Uberlândia carlosmenezesjunior@gmail.com

Marco Antonio da Silva Ramos 2 Universidade de São Paulo masilvaramos@gmail.com 


\section{Resumo}

Este artigo apresenta os resultados das experimentações realizadas no processo de criação de dois arranjos vocais que tiveram como principais alimentadores os elementos composicionais levantados durante o processo de análise estilística dos álbuns fonográficos do grupo de músicos conhecidos pelo termo Clube da Esquina. Assim, visa expor as possibilidades artísticas que podem emergir a partir da exploração da ideia de que a análise estilística também pode se inserir como recurso relevante dentro da dinâmica de apreensão e experimentação dos parâmetros de estruturação musical inerentes ao processo de criação de arranjos para grupos vocais. O primeiro arranjo foi o da canção Milagre dos Peixes, de Milton Nascimento e Fernando Brant, e o segundo da canção Chovendo na Roseira, de Tom Jobim. Por fim, é apresentada uma breve discussão de cunho teórico-reflexivo acerca das possibilidades que tal abordagem pôde oferecer nesta pesquisa e perspectivas sobre processos criativos no âmbito do arranjo vocal de repertório da música popular urbana.

Palavras-chave: Arranjo vocal; Clube da Esquina; canção; análise estilística.

\section{Abstract}

The present article presents results of creative processes regarding vocal arrangement based on the compositional elements of Clube da Esquina. Thus, it aims to expose the artistic possibilities that can emerge from the exploration of the idea that stylistic analysis can also be inserted as a relevant resource within the dynamics of apprehension and experimentation of the musical structuring parameters inherent to the process of creating arrangements for groups vocals. The first arrangement was for the song Milagre dos Peixes by Milton Nascimento and Fernando Brant and the second for the song Chovendo na Roseira by Tom Jobim. Finally, a brief discussion theoretical-reflective is presented about the possibilities that such an approach could offer in this research and perspectives on creative processes within the scope of the vocal arrangement of urban popular music.

Keywords: Vocal arrangement; The Corner Club; song; stylistic analysis.

\footnotetext{
1 É docente adjunto dos cursos de graduação e pós-graduação em música da Universidade Federal de Uberlândia atuando na área de música popular (harmonia, arranjo e história). Doutor em música pela ECA/USP na área de processos de criação musical. Possui Bacharelado em Violão e Licenciatura Plena pela UFU. Coordenador do laboratório de produção musical da UFU. Fundador e integrante do quarteto vocal VagaMundo desde de 1997.

2 Professor Titular em Regência Coral no Departamento de Música da Escola de Comunicações e Artes da Universidade de São Paulo, onde coordena o COMUNICANTUS, Laboratório Coral e o Curso de Regência. É orientador pleno do PPGMUSICA em Performance em Regência Coral e também em Questões Interpretativas na mesma Escola. Atualmente é Diretor do CORALUSP. Coral da Universidade de São Paulo.
} 
O presente texto está vinculado a uma pesquisa de doutorado concluída. ${ }^{3} \mathrm{~A}$ proposta aqui é a de apresentar os resultados das experimentações realizadas no processo de criação de dois arranjos vocais que tiveram como principais alimentadores os elementos composicionais levantados durante o processo de análise estilística dos álbuns fonográficos do grupo de músicos conhecido pelo termo Clube da Esquina. Assim, visa expor as possibilidades artísticas que podem emergir a partir da exploração da ideia de que a análise estilística também pode se inserir como recurso relevante dentro da dinâmica de apreensão e experimentação dos parâmetros de estruturação musical inerentes ao processo de criação de arranjos para grupos vocais. Busca refletir sobre como uma experiência de imersão em um determinado repertório, no caso, do Clube da Esquina, pode angariar recursos composicionais que, após analisados, teorizados e interiorizados, retornam ressignificados e recontextualizados, expandindo o âmbito do processo de expressão artística e de constituição da própria identidade poética do arranjador, sem que tais recursos se tornem uma espécie de "resgate de sonoridade", tampouco de "receituário" (pois não visam criar arranjos que "soem ao estilo" do grupo estudado).

Quanto ao termo Clube da Esquina, embora seja muito conhecido entre os apreciadores da música popular brasileira como designação de um grupo de músicos ligados à cultura mineira, não existe um consenso em relação à sua definição e delimitação. Há divergência tanto entre os músicos vinculados ao Clube da Esquina quanto entre críticos e pesquisadores. Esta expressão aparece na bibliografia e nos depoimentos de diversas formas, seja como representação de um grupo de amigos, de uma formação cultural, de um movimento, de um simples rótulo da mídia, entre outras concepções (elas não são, necessariamente, excludentes). Adoto aqui a interpretação do Clube da Esquina como formação cultural, amplamente discutida nos trabalhos de Luiz Garcia (2000, 2006) e Sheyla Diniz (2012). Em síntese, o termo formação cultural, proposto por Raymond Williams, representa em certa medida agrupamentos "identificáveis como movimentos e tendências conscientes (literários, artísticos, filosóficos e científicos) que em geral podem ser percebidos com facilidade, de acordo com suas produções formativas" (WILLIAMS, 1979, p.120). Em um dos tipos de organicidade interna que caracterizam as formações culturais "[...] existe associação consciente ou identificação grupal, manifestada de modo informal ou ocasional, ou, por vezes, limitada ao trabalho em conjunto ou a relações de caráter mais geral" (WILLIAMS, 1992, p.35). No caso do Clube da Esquina, pode-se considerar que o período que vai do final da década de 1960 até o final da década de 1970 é onde se concentra a atuação do grupo como formação cultural. Os principais nomes que compõem o Clube da Esquina são: Milton Nascimento, Lô Borges, Toninho Horta, Beto Guedes, Wagner Tiso, Márcio Borges, Fernando Brant, Ronaldo Bastos, Robertinho Silva, Novelli, Tavinho Moura, Flávio Venturini, entre outros.

O texto inicia com a apresentação de uma breve síntese de alguns dados levantados na pesquisa considerados relevantes para o bom entendimento do presente arti-

3 MENEZES JÚNIOR, C. R. F. Os elementos composicionais do Clube da Esquina como alimentadores de processos criativos de arranjos vocais de canções populares brasileiras. 2016. 562 f. Tese (Doutorado em Música) - Escola de Comunicações e Artes, Universidade de São Paulo, São Paulo, 2016. Disponivel em: https://teses.usp.br/teses/disponiveis/27/27158/tde-05052017-114221/pt-br.php. 
go. Assim, começa com um resumo dos resultados obtidos no processo analítico dos 22 discos produzidos pelo Clube da Esquina nos anos de 1967 a 1979 que resultaram na configuração de um conjunto de 22 elementos composicionais representativo das características estilísticas do grupo. Posteriormente, detalha-se o processo de criação de dois arranjos vocais e como os elementos composicionais do Clube da Esquina se concatenaram com as experimentações quanto ao tratamento harmônico, das interações rítmicas, texturais, timbrísticas e formais, demonstrando nos próprios arranjos tais experimentações. O primeiro arranjo foi para coro misto à capela da canção Milagre dos peixes, de Milton Nascimento e Fernando Brant. O segundo para trio vocal feminino e violão da canção Chovendo na roseira, de Tom Jobim. A hipótese levantada é a de que, ao analisar a organicidade interna das criações musicais que constituem a produção fonográfica do Clube da Esquina no período abordado, abre-se a possibilidade de vislumbrar um conjunto de técnicas e procedimentos de criação musical que pode ser aplicado em arranjos vocais de canções diversas (tanto internas quanto externas ao repertório do Clube da Esquina). É importante reforçar que tal abordagem não tem o propósito de "mimetizar" a sonoridade do grupo pesquisado, mas busca ampliar o espectro de ferramentas que o arranjador lança mão no seu processo autoral. Por fim, é apresentada uma breve discussão de cunho teórico-reflexivo acerca das possibilidades que tal abordagem pôde oferecer nessa pesquisa e perspectivas sobre processos criativos no âmbito do arranjo vocal de repertório da música popular urbana.

O termo música popular está sendo adotado aqui a partir de um delineamento das características gerais usualmente encontradas na bibliografia sobre esse tema abordadas na tese de Baia (2010). Assim, entende-se por música popular a música urbana que surgiu a partir do final do século XIX, concomitantemente com crescimento das grandes cidades, e com uma forte ligação com o mercado. Esta música, seja instrumental ou na modalidade canção, tem caráter massivo (embora não em sua totalidade) e foi se constituindo a partir de matizes socioculturais diversos, além de ter como principal suporte o registro fonográfico. De acordo com Baia (2010), não quer dizer que não tenham existido outras práticas musicais que pudessem ser classificadas como populares, porém já é comum nas pesquisas acadêmicas atuais associar à expressão música popular o caráter urbano. Os motivos de utilizar tal termo, diferenciando-o de outros "fazeres musicais", são de cunho analítico e não valorativo. Visa entender de forma mais precisa e adequada as peculiaridades e práticas idiossincrásicas inerentes a cada universo cultural, possibilitando identificar seus pontos de interseção e disjunção, sem hierarquizações, assim como vislumbrar de que forma os recursos e "hábitos" se inserem no processo de construção de determinada "tradição" no que tange às dinâmicas de produção e recepção de música que variam de acordo com o contexto cultural.

\section{A pesquisa}

A criação e interpretação de arranjos vocais de canções populares no Brasil já se tornaram procedimentos poéticos e interpretativos consolidados entre os grupos co- 
rais das mais diversas formações. Como a demanda por arranjos vocais/corais de música popular urbana cresceu, também cresceu o interesse, por parte de alguns músicos, em aprender a criar tais arranjos. Diante disso, algumas questões surgem: como se dá o processo de formação de um arranjador vocal? Quais conhecimentos teórico-práticos são relevantes nessa formação? Em quais contextos esses conhecimentos surgem? Em quais contextos eles se aplicam de forma adequada? Não existe resposta simples, única e geral. Os caminhos são múltiplos. Por vezes, determinado repertório instiga o estudo de seus elementos constitutivos, visando ao domínio de um tipo de sonoridade e buscando ressignificá-los no contexto de seu próprio trabalho de invenção artística.

Marco Antonio da Silva Ramos, em sua tese de livre-docência "O Ensino da Regência Coral", aponta o papel do intérprete como gerador de conhecimento teórico, além de sua atribuição de criação artística. Segundo Ramos (2003),

\begin{abstract}
O intérprete que busca uma concepção própria para as obras que apresenta é, ao mesmo tempo, um usuário da área teórica e um criador de teoria. Defendo esta ideia na medida em que, ainda que não seja o próprio intérprete a discorrer ou clarificar seus pontos de vista, frequentemente o artista acaba gerando conhecimento novo que altera, necessariamente, tudo o que antes se escreveu e se pensou sobre a obra interpretada (RAMOS, 2003, p.51).
\end{abstract}

Estendo esta ideia ao arranjador que também busca uma concepção própria para as obras escolhidas. Na música popular, o papel do arranjador é de grande importância. Nela o resultado final de uma obra pode ser fruto da somatória das "poéticas" de vários artistas (tais como compositores, arranjadores, instrumentistas, cantores etc.). Assim, temos no produto fonográfico fonte de investigação destas novas concepções. Consequentemente, novos conhecimentos teóricos podem ser ressignificados e aplicados nas mais diversas práticas de criação musical.

É nessa perspectiva que a pesquisa está localizada, ou seja, busca investigar estratégias para elaboração de arranjos vocais a partir da análise dos elementos composicionais presentes nos fonogramas produzidos pelo Clube da Esquina. Em suma, a pergunta central foi: como os elementos composicionais presentes nas obras do conjunto de músicos conhecidos como Clube da Esquina podem contribuir, como recursos de estruturação musical, na elaboração de arranjos vocais de música popular urbana?

A pertinência da proposta apresentada na presente pesquisa encontra-se justamente na oportunidade de disponibilizar um trabalho dentro da temática de arranjo vocal de música popular urbana com uma abordagem que busca efetivar a integração entre escuta analítica e escuta poética visando ampliar o horizonte de possibilidades de articulação de sonoridades.

\title{
2. Categorização dos elementos composicionais presentes nos dis- cos estudados
}

O Clube da Esquina, apesar de ter uma produção expressiva e de ter conquistado prestígio dentro e fora do Brasil, só começou a aparecer de forma significativa como 
tema central de livros e trabalhos acadêmicos a partir da segunda metade da década de noventa do século passado. Memoristas, jornalistas, músicos e pesquisadores começaram a investigar as relações que o Clube da Esquina estabeleceu ao longo da história da música popular urbana no Brasil visando situá-lo de forma mais precisa a partir de perspectivas diversas, seja pela ótica da sociologia, da história, da musicologia ou dos estudos linguísticos. A seguir, um mapeamento dos principais trabalhos acadêmicos e não acadêmicos sobre o Clube da Esquina por ordem cronológica até 2016, ano de conclusão da pesquisa.

\begin{tabular}{|c|c|}
\hline 1996 & $\begin{array}{l}\text { BORGES, Márcio. Os sonhos não envelhecem: histórias do Clube da Esquina. 1. ed. São Paulo: } \\
\text { Geração, } 1996 .\end{array}$ \\
\hline 1998 & $\begin{array}{l}\text { VIEIRA, Francisco Carlos Soares Fernandes. Pelas esquinas dos anos 70: utopia e poesia no } \\
\text { Clube da Esquina. 1998. } 132 \text { f. Dissertação (Mestrado em Poética) - Universidade Federal do } \\
\text { Rio de Janeiro, Rio de Janeiro, } 1998 \text {. }\end{array}$ \\
\hline 2000 & $\begin{array}{l}\text { GARCIA, Luiz Henrique Assis. Coisas que ficaram muito tempo por dizer: o Clube da Esqui- } \\
\text { na como formação cultural. } 2000.154 \text { f. Dissertação (Mestrado em História) - Universidade } \\
\text { Federal de Minas Gerais, Belo Horizonte, } 2000 \text {. }\end{array}$ \\
\hline 2000 & $\begin{array}{l}\text { RODRIGUES, Mauro. O modal na música de Milton Nascimento. Dissertação (Mestrado em } \\
\text { Musicologia) - Conservatório Brasileiro de Música do Rio de Janeiro, Rio de Janeiro, } 2000 .\end{array}$ \\
\hline 2000 & $\begin{array}{l}\text { TEDESCO, Cybelle Angélique Ribeiro. De Minas, mundo: a imagem poético-musical do Clube } \\
\text { da Esquina. 2000. } 210 \mathrm{f} \text {. Dissertação (Mestrado em Multimeios) - Universidade Estadual de } \\
\text { Campinas, Campinas, 2000. }\end{array}$ \\
\hline 2002 & $\begin{array}{l}\text { CORRÊA, Luiz Otávio. Clube da Esquina e Belo Horizonte: romantismo revolucionário numa } \\
\text { cidade de formação ambígua. Dissertação (Mestrado em História) - Pontifícia Universidade } \\
\text { Católica de Minas Gerais, Belo Horizonte, } 2002 \text {. }\end{array}$ \\
\hline 2003 & $\begin{array}{l}\text { SILVA, Carlos Alberto Silva da. A negritude através de Maria Maria de Milton Nascimento. } \\
\text { Dissertação (Mestrado em Literatura) - Universidade Federal de Santa Catarina, Florianópolis, } \\
2003 .\end{array}$ \\
\hline 2004 & $\begin{array}{l}\text { STARLING, Heloísa. Coração americano: panfletos e canções do Clube da Esquina. In: REIS, } \\
\text { Daniel Aarão; RIDENTI, Marcelo e MOTTA, Rodrigo Patto Sá (org.). O golpe e a ditadura militar: } \\
40 \text { anos depois (1964-2004). São Paulo: Edusc, } 2004 .\end{array}$ \\
\hline 2005 & $\begin{array}{l}\text { NUNES, Thais G. A. A sonoridade especifica do Clube da Esquina. 2005. } 175 \text { f. Dissertação } \\
\text { (Mestrado em Música) - Instituto de Artes, Universidade Estadual de Campinas, Campinas, } \\
2005 .\end{array}$ \\
\hline 2006 & 06. \\
\hline 2006 & $\begin{array}{l}\text { OLIVEIRA, Rodrigo Francisco. Mil tons de Minas: Milton Nascimento e o Clube da Esquina - } \\
\text { cultura, resistência e mineiridade na música popular brasileira. 2006. } 134 \text { f. Dissertação (Mes- } \\
\text { trado em História) - Universidade Federal de Uberlândia, Uberlândia, 2006. }\end{array}$ \\
\hline 2006 & $\begin{array}{l}\text { GARCIA, Luiz Henrique Assis. Na esquina do mundo: trocas culturais na música popular } \\
\text { brasileira através da obra do Clube da Esquina (1960-1980). 2006. } 281 \text { f. Tese (Doutorado em } \\
\text { História) - Faculdade de Filosofia e Ciências Humanas, Universidade Federal de Minas Gerais, } \\
\text { Belo Horizonte, } 2006 \text {. }\end{array}$ \\
\hline 2007 & $\begin{array}{l}\text { SBERNI JUNIOR, Cleber. O álbum na indústria fonográfica: contracultura e o Clube da Esquina } \\
\text { em 1972. Dissertação (Mestrado em História) - Unesp, Franca, } 2007 .\end{array}$ \\
\hline 2009 & $\begin{array}{l}\text { MARTINS, Bruno Viveiros. Som imaginário: a reinvenção da cidade nas canções do Clube da } \\
\text { Esquina. Belo Horizonte: Ed. UFMG, } 2009 \text {. }\end{array}$ \\
\hline 2009 & $\begin{array}{l}\text { NICODEMO, Thais Lima. Terra dos pássaros: uma abordagem sobre as composições de Toni- } \\
\text { nho Horta. 2009. } 215 \text { f. Dissertação (Mestrado em Música) - Universidade Estadual de Campi- } \\
\text { nas, Campinas, } 2009 \text {. }\end{array}$ \\
\hline
\end{tabular}




\begin{tabular}{ll}
\hline 2010 & $\begin{array}{l}\text { CANTON, Ciro Augusto Pereira. Nuvem no céu e raiz: romantismo revolucionário e mineirida- } \\
\text { de em Milton Nascimento e no Clube da Esquina (1970-1983). 2020. } 171 \text { f. Dissertação (Mes- } \\
\text { trado em História) - UFSJ, São João del-Rei, 2010. }\end{array}$ \\
\hline $2010 \begin{array}{l}\text { SOUZA, Alberto Carlos de. Minas e Geraes: um recorte na cultura e na história através de } \\
\text { Milton Nascimento. Dissertação (Mestrado em História) - Universidade Salgado de Oliveira, } \\
\text { Niterói, 2010. }\end{array}$ \\
\hline 2010 & $\begin{array}{l}\text { VILELA, Ivan. Nada ficou como antes. Revista USP: dossiê música brasileira, São Paulo, n. 87, p. } \\
14-27,2010 .\end{array}$ \\
\hline 2010 & $\begin{array}{l}\text { VITENTI, Ada Dias Pinto. Uma certa musicalidade nas esquinas de Minas (1960-1970). } 130 \text { f. } \\
\text { Dissertação (Mestrado em História) - Universidade de Brasília, Brasília, 2010. }\end{array}$ \\
\hline 2010 & $\begin{array}{l}\text { CANÇADO, Wilson Lopes. Novena, Crença e Gira Girou de Milton Nascimento e Márcio Bor- } \\
\text { ges: análise de suas três primeiras composições criadas em uma noite de 1964. 2010. 146 f. } \\
\text { Dissertação (Mestrado em Música) - UFMG, Belo Horizonte, 2010. }\end{array}$ \\
\hline 2011 & $\begin{array}{l}\text { MOREIRA, Maria Beatriz Cyrino. Fusões de gêneros e estilos na produção musical da banda } \\
\text { Som Imaginário. 266 f. Dissertação (Mestrado em Música) - Unicamp, Campinas, 2011. }\end{array}$ \\
\hline 2012 & $\begin{array}{l}\text { DINIZ, Sheyla Castro. "Nuvem Cigana": a trajetória do Clube da Esquina no campo da MPB. } \\
\text { 2012. 231 f. Dissertação (Mestrado em Sociologia) - Unicamp, Campinas, 2012. }\end{array}$ \\
\hline 2013 & AMARAL, Chico. A música de Milton Nascimento. Belo Horizonte: Gomes, 2013. \\
\hline 2015 & $\begin{array}{l}\text { NUNES, Thais G. A. A voz de Milton Nascimento em presença. 2015. } 96 \text { f. Tese (Doutorado em } \\
\text { Música) - Instituto de Artes, Universidade Estadual de Campinas, Campinas, 2015. }\end{array}$ \\
\hline
\end{tabular}

Tab. 1: Mapa geral dos principais trabalhos acadêmicos e não acadêmicos sobre o Clube da Esquina organizados por ordem cronológica até 2016

Os trabalhos de Nunes (2005), Nicodemos (2009), Cançado (2010), Moreira (2011) e Nunes (2015) se destacam, no que tange aos propósitos do presente artigo, por também apresentarem estudos acerca de aspectos da estruturação musical contidos em fonogramas do repertório do Clube da Esquina. Evidentemente, cada um com um foco específico.

Conforme abordado anteriormente, o período que vai do final da década de 1960 até o final da década de 1970 é onde se concentra a atuação do grupo como formação cultural. Assim, os discos selecionados para esse estudo foram os lançamentos ocorridos de 1967 (ano do primeiro álbum completo de Milton Nascimento) até 1979, totalizando 22 discos. Ao longo do processo de escuta analítica, percebeu-se que alguns procedimentos de estruturação musical apareciam de forma recorrente. Não significa que todos ocorriam simultaneamente, pois eram combinados de modo muito variado em cada disco. Percebeu-se também alguns procedimentos pouco usuais que não eram, necessariamente, tão recorrentes assim, porém apresentavam-se como soluções criativas relevantes.

Após ouvir atentamente todos os 269 fonogramas e anotar os elementos composicionais percebidos, relativos à construção harmônica, melódica, rítmica, formal, timbrística, entre outras, buscou-se organizar todos eles com o intuito de vislumbrar com que frequência apareciam e em quais obras. Deste modo, foram elencados 22 elementos composicionais vistos como significativos para os propósitos da pesquisa.

É importante salientar que esses 22 elementos composicionais não representam uma lista definitiva, completa, acabada, dos recursos e procedimentos que constituem a sonoridade do Clube da Esquina. Esse conjunto de elementos apresentado aqui pode ser visto como uma das possibilidades de síntese. Outras configurações são possíveis, 
assim como um conjunto mais amplo, com diversificação maior de foco, tais como as questões que envolvem a estruturação e os temas das letras, as combinações instrumentais, as sonoridades exploradas no canto, entre outras que podem ser abordadas em trabalhos futuros. Os 22 elementos composicionais elencados são os seguintes: ${ }^{4}$

1) - Hibridismo tonal/modal;

2) - Modalismo misto; 5

3) - Elemento "Pedal";

4) - Uso do acorde Vm7;

5) - Uso do acorde bll;

6) - Presença do acorde com a quarta suspensa (sus4);

7) - Uso de acordes com a quarta suspensa (sus4) em outros graus que não sejam

○ V ou SubV primários ou secundários;

8) - Uso dos acordes IV7M(\#11) ou bll7M(\#11) como opção de Dominante;

9) - Uso do acorde \#IVm7(b5) como opção de Subdominante;

10) - Construção de sequências harmônicas pouco usuais com acordes menores;

11) - Acordes de mesma estrutura com distância de terça;

12) - Presença das notas de tensão na construção melódica e/ou harmônica;

13) - Acordes em quartas;

14) - Acordes com a sétima no baixo;

15) - Progressões cromáticas na harmonia;

16) - Polirritmia;

17) - Seções fortemente contrastantes;

18) - Utilização de fórmulas de compasso pouco usuais, grande liberdade com a métrica ou métricas misturadas;

19) - Aberturas vocais a duas ou mais vozes e/ou presença de contracanto instrumental;

20) - Presença de riff instrumental;

21) - Presença de saltos melódicos de sétima ou trítono;

22) - Presença de arpejo em terças na construção melódica.

\footnotetext{
$4 \quad$ Como o foco principal do presente artigo é o processo de criação dos arranjos vocais, optou-se por não apresentar o detalhamento de cada um dos 22 elementos elencados, pois demandaria um espaço muito grande somente para isso, o que poderia desviar do foco. Porém, alguns deles, considerados mais relevantes para os objetivos do artigo, estão presentes de forma sintética em notas de rodapé ou incorporados ao longo do texto principal, especialmente nas seções em que os dois arranjos vocais são esmiuçados. Caso haja o interesse em aprofundar a leitura acerca desse item, com discussões bastante detalhadas e exemplificadas desses elementos composicionais, basta consultar a tese por meio do link apresentado nas referências.

50 termo modalismo misto é utilizado no presente texto para designar o procedimento composicional em que as bases de estruturação são essencialmente modais (e não tonais), porém com os modos misturados, tanto na constituição melódica quanto na harmônica. Com isso, os "temperos modais" se combinam, e o leque de opções dentro do próprio sistema se expande. Quando falamos em hibridismo tonal/modal, estamos nos referindo a procedimentos harmônicos e melódicos que se conectam com as práticas tonais e modais e que se misturam em uma mesma composição, visando explorar os efeitos típicos desses dois sistemas. Chediak (1986, v.1, p.121) utiliza o termo modalismo puro quando apenas um modo específico é utilizado na geração da melodia e harmonia. Para ele, modalismo misto é quando ocorre a mistura entre os modos ou deles com o tonalismo, ou seja, o hibridismo tonal/modal é visto como uma forma particular de modalismo misto. Diferentemente de Chediak (1986, v.1, p.121), optou-se, no presente texto, por tratar os dois termos de forma separada, pois percebeu-se que os efeitos da combinação intersistemas (tonal/modal) se diferenciavam dos efeitos das combinações intrassistema (no caso o modal). Sendo assim, o termo modalismo misto é utilizado para analisar o tratamento dado apenas ao sistema modal, seja quando ele aparece em uma parcela da música, seja quando a mesma é constituída integralmente por ele. Se uma música que apresenta o hibridismo tonal/modal tiver na sua "seção modal" mais de um modo sendo combinado, ela também estará dentro da categoria de modalismo misto. Em suma, em uma composição pode aparecer apenas o hibridismo tonal/modal, apenas o modalismo misto ou os dois juntos.
} 
Todos os acordes e melodias foram analisados diretamente das gravações e passaram por uma verificação por meio da visualização dos respectivos espectrogramas no software Sonic Visualiser. No momento da pesquisa, aproximadamente $50 \%$ das faixas já tinham sido publicadas (em forma de partituras com cifras) em songbooks ou em outros trabalhos acadêmicos, porém mesmo estas passaram por uma verificação em relação a harmonia e melodia. É importante salientar que no conjunto dos 269 fonogramas, muitos são regravações de uma mesma composição com novo arranjo. Com isso, o número total de composições diferentes é 221.

Como resultado dessa etapa da pesquisa, foram geradas tabelas que mostram com que frequência cada um dos 22 elementos composicionais elencados aparecem em cada disco e em cada faixa. A Tab. 2 é uma das tabelas que sintetizam esses dados. Os números das colunas representam os seguintes elementos: 1- Hibridismo tonal/modal; 2- Modalismo misto; 3- Elemento "Pedal"; 4- Uso do acorde Vm7; 5- Uso do acorde bll; 6- Presença do acorde com a quarta suspensa (sus4); 7- Uso de acordes com a quarta suspensa (sus4) em outros graus que não sejam o V ou SubV primários ou secundários; 8- Uso dos acordes IV7M(\#11) ou bll7M(\#11) como opção de Dominante; 9- Uso do acorde \#IVm7(b5) como opção de Subdominante; 10- Construção de sequências harmônicas pouco usuais com acordes menores; 11- Acordes de mesma estrutura com distância de terça; 12- Presença das notas de tensão na construção melódica e/ou harmônica; 13- Acordes em quartas; 14- Acordes com a sétima no baixo; 15- Progressões cromáticas na harmonia; 16- Polirritmia; 17- Seções fortemente contrastantes; 18- Utilização de fórmulas de compasso pouco usuais, grande liberdade com a métrica ou métricas misturadas; 19- Aberturas vocais a duas ou mais vozes e/ou presença de contracanto instrumental; 20- Presença de riff instrumental; 21- Presença de saltos melódicos de sétima ou trítono; 22- Presença de arpejo em terças na construção melódica. O número dentro dos quadrados indica a quantidade de faixas em que cada elemento foi detectado no disco específico.

\begin{tabular}{|c|c|c|c|c|c|c|c|c|c|c|c|c|c|c|c|c|c|c|c|c|c|c|}
\hline $\begin{array}{c}\text { Discos } \\
\text { (22 discos, } 269 \text { faixas) }\end{array}$ & 1 & 2 & 3 & 4 & 5 & 6 & 7 & 8 & 9 & 10 & 11 & 12 & 13 & 14 & 15 & 16 & 17 & 18 & 19 & 20 & 21 & 22 \\
\hline $\begin{array}{c}\text { Milton Nascimento / } \\
\text { Travessia } \\
\text { Milton Nascimento - } 1967\end{array}$ & $\begin{array}{l}\checkmark \\
7\end{array}$ & $\begin{array}{l}2 \\
8\end{array}$ & $\begin{array}{l}\checkmark \\
8\end{array}$ & $\begin{array}{l}\checkmark \\
7\end{array}$ & $\begin{array}{l}\checkmark \\
6\end{array}$ & $\begin{array}{l}\checkmark \\
9\end{array}$ & $\begin{array}{l}\checkmark \\
6\end{array}$ & $\begin{array}{l}\mathbf{3} \\
3\end{array}$ & $\begin{array}{l}\checkmark \\
2\end{array}$ & $\begin{array}{l}2 \\
3\end{array}$ & $\begin{array}{l}\checkmark \\
7\end{array}$ & $\begin{array}{c}\checkmark \\
10\end{array}$ & $\begin{array}{l}\checkmark \\
3\end{array}$ & $\begin{array}{l}\checkmark \\
7\end{array}$ & $\begin{array}{l}\checkmark \\
1\end{array}$ & & $\begin{array}{l}\checkmark \\
5\end{array}$ & & $\begin{array}{l}\checkmark \\
9\end{array}$ & $\begin{array}{l}\checkmark \\
4\end{array}$ & $\begin{array}{l}\checkmark \\
5\end{array}$ & $\begin{array}{l}\checkmark \\
6\end{array}$ \\
\hline $\begin{array}{c}\text { Courage } \\
\text { Milton Nascimento - } 1969 \\
\end{array}$ & $\begin{array}{l}\checkmark \\
7 \\
\end{array}$ & $\begin{array}{l}\checkmark \\
8\end{array}$ & $\begin{array}{l}\checkmark \\
9\end{array}$ & $\begin{array}{l}\checkmark \\
6\end{array}$ & $\begin{array}{l}\checkmark \\
3\end{array}$ & $\stackrel{\checkmark}{8}$ & $\begin{array}{l}\checkmark \\
5\end{array}$ & $\begin{array}{l}\checkmark \\
2\end{array}$ & $\begin{array}{l}\checkmark \\
2\end{array}$ & $\begin{array}{l}\checkmark \\
4\end{array}$ & $\begin{array}{l}\checkmark \\
8\end{array}$ & $\begin{array}{c}2 \\
10\end{array}$ & $\begin{array}{l}\checkmark \\
3\end{array}$ & $\begin{array}{l}\checkmark \\
6\end{array}$ & $\begin{array}{l}\checkmark \\
2\end{array}$ & $\begin{array}{l}\checkmark \\
1\end{array}$ & $\begin{array}{l}2 \\
5\end{array}$ & & $\begin{array}{l}2 \\
8\end{array}$ & $\begin{array}{l}2 \\
6\end{array}$ & $\begin{array}{l}\checkmark \\
3\end{array}$ & $\begin{array}{l}\checkmark \\
7\end{array}$ \\
\hline $\begin{array}{c}\text { Milton Nascimento } \\
\text { Milton Nascimento - } 1969\end{array}$ & $\begin{array}{r}\checkmark \\
7\end{array}$ & $\begin{array}{l}\checkmark \\
6\end{array}$ & $\begin{array}{l}\checkmark \\
7\end{array}$ & $\begin{array}{l}\checkmark \\
4\end{array}$ & $\begin{array}{l}\checkmark \\
2\end{array}$ & $\begin{array}{c}\checkmark \\
10\end{array}$ & $\begin{array}{l}\checkmark \\
5\end{array}$ & & $\begin{array}{l}\checkmark \\
1\end{array}$ & $\begin{array}{l}\checkmark \\
1\end{array}$ & $\begin{array}{l}\checkmark \\
8\end{array}$ & $\begin{array}{c}2 \\
10\end{array}$ & $\begin{array}{l}\checkmark \\
4\end{array}$ & $\begin{array}{l}\checkmark \\
8\end{array}$ & $\begin{array}{l}\checkmark \\
1\end{array}$ & $\begin{array}{l}\checkmark \\
5\end{array}$ & $\begin{array}{l}\checkmark \\
5\end{array}$ & $\begin{array}{l}\checkmark \\
2\end{array}$ & $\begin{array}{l}r \\
6\end{array}$ & $\begin{array}{r}\checkmark \\
2\end{array}$ & $\begin{array}{l}\checkmark \\
1\end{array}$ & $\begin{array}{l}\checkmark \\
5\end{array}$ \\
\hline $\begin{array}{c}\text { Som Imaginário } \\
\text { Som Imaginário - } 1970\end{array}$ & $\begin{array}{l}\checkmark \\
1 \\
\end{array}$ & $\begin{array}{l}\checkmark \\
5\end{array}$ & $\begin{array}{r}\checkmark \\
2 \\
\end{array}$ & $\begin{array}{l}\checkmark \\
2 \\
\end{array}$ & $\begin{array}{l}\checkmark \\
2 \\
\end{array}$ & $\begin{array}{r}\checkmark \\
2\end{array}$ & & & $\begin{array}{l}\checkmark \\
1\end{array}$ & & $\begin{array}{l}\checkmark \\
2 \\
\end{array}$ & $\begin{array}{l}\checkmark \\
1 \\
\end{array}$ & $\begin{array}{l}\checkmark \\
1 \\
\end{array}$ & $\begin{array}{l}\checkmark \\
3 \\
\end{array}$ & $\begin{array}{l}\checkmark \\
2\end{array}$ & & $\begin{array}{r}\checkmark \\
4\end{array}$ & $\begin{array}{l}\checkmark \\
1 \\
\end{array}$ & $\begin{array}{l}r \\
6 \\
\end{array}$ & $\begin{array}{r}\checkmark \\
3\end{array}$ & & $\begin{array}{l}\checkmark \\
2\end{array}$ \\
\hline $\begin{array}{c}\text { Milton } \\
\text { Milton Nascimento - } 1970\end{array}$ & $\begin{array}{l}\checkmark \\
5 \\
\end{array}$ & $\begin{array}{l}\checkmark \\
9\end{array}$ & $\begin{array}{l}\checkmark \\
6 \\
\end{array}$ & $\begin{array}{l}\checkmark \\
9 \\
\end{array}$ & $\begin{array}{l}\checkmark \\
2 \\
\end{array}$ & $\begin{array}{c}\checkmark \\
11\end{array}$ & $\begin{array}{r}\checkmark \\
7 \\
\end{array}$ & & $\begin{array}{l}\checkmark \\
3\end{array}$ & $\begin{array}{l}\checkmark \\
5\end{array}$ & $\begin{array}{l}\checkmark \\
5\end{array}$ & $\begin{array}{r}2 \\
12\end{array}$ & $\begin{array}{l}\checkmark \\
4\end{array}$ & $\begin{array}{l}\checkmark \\
7\end{array}$ & $\begin{array}{l}2 \\
3\end{array}$ & $\begin{array}{l}\checkmark \\
7\end{array}$ & $\begin{array}{l}\checkmark \\
7\end{array}$ & $\begin{array}{l}2 \\
3\end{array}$ & $\begin{array}{l}2 \\
8\end{array}$ & $\begin{array}{l}\checkmark \\
5\end{array}$ & $\begin{array}{l}\checkmark \\
4\end{array}$ & $\begin{array}{l}\checkmark \\
6\end{array}$ \\
\hline $\begin{array}{c}\text { Som Imaginário } \\
\text { Som Imaginário - } 1971\end{array}$ & $\begin{array}{l}\checkmark \\
4\end{array}$ & $\begin{array}{r}\checkmark \\
4\end{array}$ & $\begin{array}{l}\checkmark \\
3 \\
\end{array}$ & $\begin{array}{l}\checkmark \\
1 \\
\end{array}$ & $\begin{array}{l}2 \\
2 \\
\end{array}$ & $\begin{array}{l}\checkmark \\
6\end{array}$ & $\begin{array}{l}2 \\
3 \\
\end{array}$ & & & & $\begin{array}{r}\checkmark \\
4\end{array}$ & 7 & & $\begin{array}{l}2 \\
3 \\
\end{array}$ & $\begin{array}{l}2 \\
3 \\
\end{array}$ & & $\begin{array}{l}2 \\
5 \\
\end{array}$ & & $\begin{array}{l}\checkmark \\
2 \\
\end{array}$ & $\begin{array}{l}2 \\
3 \\
\end{array}$ & $\begin{array}{l}\checkmark \\
1 \\
\end{array}$ & $\begin{array}{l}\checkmark \\
2 \\
\end{array}$ \\
\hline $\begin{array}{c}\text { Clube da Esquina } \\
\text { Milton Nascimento e Lô } \\
\text { Borges - } 1972\end{array}$ & $\begin{array}{l}\checkmark \\
8\end{array}$ & $\begin{array}{c}\checkmark \\
15\end{array}$ & $\begin{array}{c}\checkmark \\
12\end{array}$ & $\begin{array}{l}\checkmark \\
8\end{array}$ & $\begin{array}{l}\checkmark \\
7\end{array}$ & $\begin{array}{c}\checkmark \\
12\end{array}$ & $\begin{array}{l}\checkmark \\
7\end{array}$ & & $\begin{array}{l}\checkmark \\
2\end{array}$ & $\begin{array}{l}\checkmark \\
2\end{array}$ & $\begin{array}{l}\checkmark \\
8\end{array}$ & $\begin{array}{c}\checkmark \\
19\end{array}$ & $\begin{array}{l}\checkmark \\
5\end{array}$ & $\begin{array}{l}\checkmark \\
5\end{array}$ & $\begin{array}{l}\mathbf{1} \\
3\end{array}$ & $\begin{array}{l}\checkmark \\
2\end{array}$ & ב̃ & $\begin{array}{l}\checkmark \\
9\end{array}$ & $\begin{array}{l}\checkmark \\
11\end{array}$ & $\begin{array}{l}\checkmark \\
9\end{array}$ & $\begin{array}{l}\checkmark \\
5\end{array}$ & $\begin{array}{l}\checkmark \\
6\end{array}$ \\
\hline $\begin{array}{c}\text { Lô Borges (disco do tênis) } \\
\text { Lô Borges - } 1972\end{array}$ & $\begin{array}{l}\checkmark \\
6\end{array}$ & $\begin{array}{l}\checkmark \\
8\end{array}$ & $\begin{array}{l}\checkmark \\
2\end{array}$ & $\begin{array}{l}\checkmark \\
3\end{array}$ & $\begin{array}{r}\checkmark \\
3\end{array}$ & $\begin{array}{l}\checkmark \\
6\end{array}$ & $\begin{array}{l}\checkmark \\
2\end{array}$ & $\begin{array}{l}\checkmark \\
2\end{array}$ & $\begin{array}{l}\checkmark \\
2\end{array}$ & $\begin{array}{l}\checkmark \\
2\end{array}$ & $\begin{array}{l}\checkmark \\
5\end{array}$ & $\begin{array}{r}\checkmark \\
10\end{array}$ & & $\begin{array}{l}\checkmark \\
5\end{array}$ & & & $\begin{array}{r}\checkmark \\
4\end{array}$ & $\begin{array}{l}\checkmark \\
2\end{array}$ & $\begin{array}{l}\checkmark \\
6\end{array}$ & $\begin{array}{l}\checkmark \\
6\end{array}$ & & $\begin{array}{l}\checkmark \\
5\end{array}$ \\
\hline
\end{tabular}




\begin{tabular}{|c|c|c|c|c|c|c|c|c|c|c|c|c|c|c|c|c|c|c|c|c|c|c|}
\hline $\begin{array}{c}\text { Discos } \\
\text { (22 discos, } 269 \text { faixas) }\end{array}$ & 1 & 2 & 3 & 4 & 5 & 6 & 7 & 8 & 9 & 10 & 11 & 12 & 13 & 14 & 15 & 16 & 17 & 18 & 19 & 20 & 21 & 22 \\
\hline $\begin{array}{c}\text { Matança do Porco } \\
\text { Som Imaginário - } 1973\end{array}$ & $\begin{array}{l}\checkmark \\
6\end{array}$ & $\begin{array}{l}\checkmark \\
6\end{array}$ & $\begin{array}{l}\checkmark \\
2\end{array}$ & $\begin{array}{l}\checkmark \\
4\end{array}$ & $\begin{array}{l}\checkmark \\
5\end{array}$ & $\begin{array}{l}2 \\
3\end{array}$ & $\begin{array}{l}\checkmark \\
2\end{array}$ & & & $\begin{array}{l}\checkmark \\
3\end{array}$ & $\begin{array}{l}\checkmark \\
5\end{array}$ & $\begin{array}{l}2 \\
8\end{array}$ & $\begin{array}{l}\checkmark \\
4\end{array}$ & $\begin{array}{l}2 \\
3\end{array}$ & $\begin{array}{l}\checkmark \\
1\end{array}$ & $\begin{array}{l}\checkmark \\
1\end{array}$ & $\begin{array}{l}\checkmark \\
6\end{array}$ & $\begin{array}{l}\checkmark \\
2\end{array}$ & $\begin{array}{l}\checkmark \\
3\end{array}$ & $\begin{array}{l}\checkmark \\
4\end{array}$ & & $\begin{array}{l}2 \\
2\end{array}$ \\
\hline $\begin{array}{c}\text { Milagre dos Peixes } \\
\text { Milton Nascimento - } 1973\end{array}$ & $\begin{array}{l}2 \\
3\end{array}$ & 10 & $\begin{array}{l}2 \\
7\end{array}$ & $\begin{array}{l}2 \\
7\end{array}$ & $\begin{array}{l} \\
4 \\
\end{array}$ & $\begin{array}{l}\checkmark \\
9\end{array}$ & $\begin{array}{l}2 \\
7\end{array}$ & $\begin{array}{l}\checkmark \\
1\end{array}$ & & \begin{tabular}{l|} 
\\
2
\end{tabular} & $\begin{array}{l} \\
6 \\
\end{array}$ & $\begin{array}{l} \\
9\end{array}$ & $\begin{array}{l}\checkmark \\
1\end{array}$ & $\begin{array}{l}2 \\
7 \\
\end{array}$ & $\begin{array}{l} \\
2\end{array}$ & $\begin{array}{l}2 \\
3\end{array}$ & $\begin{array}{l}2 \\
5\end{array}$ & $\begin{array}{l}2 \\
6\end{array}$ & $\begin{array}{l}\checkmark \\
6\end{array}$ & $\begin{array}{l}2 \\
2\end{array}$ & & $\begin{array}{l} \\
1\end{array}$ \\
\hline $\begin{array}{c}\text { (Os quatro no banheiro) } \\
\text { Beto Guedes, Danilo } \\
\text { Caymmi, Novelli, Toninho } \\
\text { Horta - } 1973\end{array}$ & $\begin{array}{l}\checkmark \\
7\end{array}$ & $\begin{array}{l}\checkmark \\
4\end{array}$ & $\begin{array}{l}\checkmark \\
5\end{array}$ & $\begin{array}{l}2 \\
3\end{array}$ & $\begin{array}{l}\checkmark \\
5\end{array}$ & $\begin{array}{l}\checkmark \\
7\end{array}$ & $\begin{array}{r}\checkmark \\
2\end{array}$ & $\begin{array}{l}\checkmark \\
2\end{array}$ & & $\begin{array}{l}\checkmark \\
1\end{array}$ & $\begin{array}{l}2 \\
3\end{array}$ & $\begin{array}{l}\checkmark \\
9\end{array}$ & $\begin{array}{l}r \\
3\end{array}$ & $\begin{array}{l}2 \\
3\end{array}$ & & $\begin{array}{l}\checkmark \\
1\end{array}$ & $\begin{array}{l}\checkmark \\
4\end{array}$ & $\begin{array}{l}\checkmark \\
1\end{array}$ & $\begin{array}{l}\checkmark \\
4\end{array}$ & & $\begin{array}{l}\checkmark \\
2\end{array}$ & $\begin{array}{l}\checkmark \\
6\end{array}$ \\
\hline $\begin{array}{c}\text { Milagre dos Peixes (Ao } \\
\text { Vivo) } \\
\text { Milton Nascimento - } 1974\end{array}$ & $\begin{array}{l}\checkmark \\
8\end{array}$ & $\begin{array}{r}\checkmark \\
11\end{array}$ & ` & $\begin{array}{l}\checkmark \\
9\end{array}$ & $\begin{array}{l}\checkmark \\
5\end{array}$ & $\begin{array}{l}\checkmark \\
11\end{array}$ & $\begin{array}{l}\checkmark \\
6\end{array}$ & $\begin{array}{l}\checkmark \\
1\end{array}$ & $\begin{array}{l}\checkmark \\
1\end{array}$ & $\begin{array}{l}\checkmark \\
4\end{array}$ & $\begin{array}{l}\checkmark \\
7\end{array}$ & $\begin{array}{l}\checkmark \\
13\end{array}$ & $\begin{array}{l}\checkmark \\
3\end{array}$ & $\begin{array}{r}\checkmark \\
8\end{array}$ & $\begin{array}{l}\checkmark \\
2\end{array}$ & $\begin{array}{l}\checkmark \\
1\end{array}$ & $\begin{array}{l}\checkmark \\
9\end{array}$ & $\begin{array}{l}\checkmark \\
7\end{array}$ & $\begin{array}{l}\checkmark \\
7\end{array}$ & $\begin{array}{l}\checkmark \\
2\end{array}$ & $\begin{array}{l}\checkmark \\
4\end{array}$ & $\begin{array}{l}r \\
3\end{array}$ \\
\hline $\begin{array}{c}\text { Minas } \\
\text { Milton Nascimento - } 1975\end{array}$ & $\begin{array}{l}\checkmark \\
5\end{array}$ & $\begin{array}{l}\checkmark \\
9\end{array}$ & $\begin{array}{l}\checkmark \\
g\end{array}$ & $\begin{array}{l}\checkmark \\
6\end{array}$ & $\begin{array}{l}\checkmark \\
2\end{array}$ & $\begin{array}{l}\checkmark \\
12\end{array}$ & $\begin{array}{l}\checkmark \\
8\end{array}$ & $\begin{array}{l}\checkmark \\
1\end{array}$ & & & $\begin{array}{l}\checkmark \\
3\end{array}$ & $\begin{array}{l}\checkmark \\
11\end{array}$ & $\begin{array}{l}\checkmark \\
1\end{array}$ & $\begin{array}{l}2 \\
3\end{array}$ & $\begin{array}{l}\checkmark \\
2\end{array}$ & $\begin{array}{l}\checkmark \\
1\end{array}$ & $\begin{array}{l}\checkmark \\
7\end{array}$ & $\begin{array}{l}\checkmark \\
7\end{array}$ & $\begin{array}{l}\checkmark \\
7\end{array}$ & $\begin{array}{l}\checkmark \\
2\end{array}$ & & $\begin{array}{l}2 \\
3\end{array}$ \\
\hline $\begin{array}{c}\text { Geraes } \\
\text { Milton Nascimento - } 1976\end{array}$ & $\begin{array}{l}\checkmark \\
5\end{array}$ & $\begin{array}{l}\checkmark \\
5\end{array}$ & $\begin{array}{l}2 \\
8\end{array}$ & $\begin{array}{l}\checkmark \\
7\end{array}$ & & $\begin{array}{l}2 \\
6\end{array}$ & & & $\begin{array}{l}\checkmark \\
1\end{array}$ & \begin{tabular}{l|l} 
\\
2
\end{tabular} & $\begin{array}{l}\checkmark \\
4\end{array}$ & $\begin{array}{l} \\
7\end{array}$ & \begin{tabular}{l|l} 
\\
1
\end{tabular} & $\begin{array}{l}\checkmark \\
4\end{array}$ & $\begin{array}{l} \\
1\end{array}$ & & $\begin{array}{l}2 \\
3\end{array}$ & $\begin{array}{l} \\
2\end{array}$ & $\begin{array}{l}\checkmark \\
9\end{array}$ & \begin{tabular}{l|l} 
\\
2
\end{tabular} & $\begin{array}{l}1 \\
2\end{array}$ & $\begin{array}{l}\checkmark \\
4\end{array}$ \\
\hline $\begin{array}{c}\text { Milton (Raça) } \\
\text { Milton Nascimento - } 1976\end{array}$ & $\begin{array}{l}2 \\
3\end{array}$ & $\begin{array}{l}2 \\
8\end{array}$ & $\begin{array}{l}2 \\
6\end{array}$ & $\begin{array}{l} \\
2\end{array}$ & $\begin{array}{l}2 \\
3\end{array}$ & $\begin{array}{l}2 \\
6\end{array}$ & $\begin{array}{l}2 \\
6\end{array}$ & & & \begin{tabular}{l|l} 
\\
1
\end{tabular} & $\begin{array}{l} \\
\end{array}$ & $\begin{array}{l} \\
8\end{array}$ & $\begin{array}{l}\checkmark \\
2\end{array}$ & $\begin{array}{l} \\
4\end{array}$ & $\begin{array}{l} \\
1\end{array}$ & & $\begin{array}{l}\checkmark \\
5\end{array}$ & $\begin{array}{l} \\
5\end{array}$ & $\begin{array}{l}\checkmark \\
4\end{array}$ & $\begin{array}{l}2 \\
3\end{array}$ & $\begin{array}{l} \\
1\end{array}$ & $\begin{array}{l} \\
1\end{array}$ \\
\hline $\begin{array}{l}\text { Maria Maria (trilha sonora } \\
\text { do balé do grupo corpo } \\
\text { com estreia em 1976) } \\
\text { Milton Nascimento - } 1976\end{array}$ & $\begin{array}{l}\checkmark \\
5\end{array}$ & $\begin{array}{r}\checkmark \\
14\end{array}$ & `े & $\begin{array}{c}\checkmark \\
10\end{array}$ & $\begin{array}{l}\checkmark \\
5\end{array}$ & $\begin{array}{l}\checkmark \\
11\end{array}$ & $\begin{array}{l}\checkmark \\
9\end{array}$ & & & $\begin{array}{l}\checkmark \\
2\end{array}$ & $\checkmark$ & $\begin{array}{l}\checkmark \\
11\end{array}$ & $\begin{array}{l}\checkmark \\
2\end{array}$ & $\begin{array}{l}\checkmark \\
5\end{array}$ & $\begin{array}{l}\checkmark \\
2\end{array}$ & $\begin{array}{l}\checkmark \\
2\end{array}$ & $\begin{array}{l}\checkmark \\
4\end{array}$ & $\checkmark$ & $\begin{array}{c}\checkmark \\
13\end{array}$ & $\begin{array}{l}\checkmark \\
5\end{array}$ & & $\begin{array}{l}\checkmark \\
2\end{array}$ \\
\hline $\begin{array}{c}\text { A página do relâmpago } \\
\text { elétrico } \\
\text { Beto Guedes - } 1977\end{array}$ & $\begin{array}{l}\checkmark \\
7\end{array}$ & $\begin{array}{l}\checkmark \\
6\end{array}$ & $\begin{array}{l}\checkmark \\
4\end{array}$ & $\begin{array}{l}\checkmark \\
5\end{array}$ & $\begin{array}{l}2 \\
3\end{array}$ & $\begin{array}{l}\checkmark \\
6\end{array}$ & $\begin{array}{l}\checkmark \\
5\end{array}$ & & $\begin{array}{l}\checkmark \\
2\end{array}$ & & $\begin{array}{l}\checkmark \\
5\end{array}$ & $\begin{array}{l}\checkmark \\
7\end{array}$ & & $\begin{array}{l}\checkmark \\
3\end{array}$ & $\begin{array}{l}\checkmark \\
1\end{array}$ & & $\begin{array}{l}\checkmark \\
4\end{array}$ & & $\begin{array}{l}\checkmark \\
5\end{array}$ & $\begin{array}{l}2 \\
3\end{array}$ & $\begin{array}{l}2 \\
3\end{array}$ & \\
\hline $\begin{array}{c}\text { Clube da Esquina } 2 \\
\text { Milton Nascimento - } 1978 \\
\end{array}$ & $\begin{array}{l}\checkmark \\
12\end{array}$ & $\begin{array}{c}2 \\
16\end{array}$ & 尚 & $\begin{array}{l}\checkmark \\
11\end{array}$ & $\begin{array}{l}\checkmark \\
7 \\
\end{array}$ & $\begin{array}{c}2 \\
19\end{array}$ & $\begin{array}{c}2 \\
12\end{array}$ & $\begin{array}{l}\checkmark \\
1 \\
\end{array}$ & $\begin{array}{l}2 \\
3 \\
\end{array}$ & \begin{tabular}{l|} 
\\
1
\end{tabular} & $\begin{array}{l}\checkmark \\
9\end{array}$ & $\begin{array}{c}2 \\
18 \\
\end{array}$ & $\begin{array}{l}\checkmark \\
5\end{array}$ & $\begin{array}{c}2 \\
12 \\
\end{array}$ & 4 & $\begin{array}{l}\checkmark \\
1\end{array}$ & $\begin{array}{c}2 \\
10\end{array}$ & $\begin{array}{l}\checkmark \\
2\end{array}$ & $\begin{array}{l}\checkmark \\
17\end{array}$ & $\begin{array}{l}\checkmark \\
2\end{array}$ & $\begin{array}{l} \\
4 \\
\end{array}$ & $\begin{array}{l}\checkmark \\
4 \\
\end{array}$ \\
\hline $\begin{array}{c}\text { Amor de índio } \\
\text { Beto Guedes - } 1978\end{array}$ & $\begin{array}{l}\checkmark \\
7 \\
\end{array}$ & $\begin{array}{l}\checkmark \\
1\end{array}$ & $\begin{array}{l}2 \\
3\end{array}$ & $\begin{array}{l}\checkmark \\
2\end{array}$ & & $\begin{array}{l}\checkmark \\
5\end{array}$ & $\begin{array}{l} \\
1\end{array}$ & & & \begin{tabular}{l|l} 
\\
1
\end{tabular} & $\begin{array}{l} \\
2\end{array}$ & $\begin{array}{l}2 \\
6\end{array}$ & & $\begin{array}{l}2 \\
6\end{array}$ & $\begin{array}{l}2 \\
3\end{array}$ & & $\begin{array}{l}\checkmark \\
4\end{array}$ & $\begin{array}{l}\checkmark \\
4\end{array}$ & $\begin{array}{l}\checkmark \\
2\end{array}$ & $\begin{array}{l}\checkmark \\
2\end{array}$ & $\begin{array}{l}2 \\
2\end{array}$ & $\begin{array}{l}\checkmark \\
2\end{array}$ \\
\hline $\begin{array}{c}\text { A Via-Láctea } \\
\text { Lô Borges - } 1979\end{array}$ & $\begin{array}{l}2 \\
6\end{array}$ & $\begin{array}{l}\checkmark \\
4\end{array}$ & $\begin{array}{l}2 \\
4\end{array}$ & $\begin{array}{l} \\
2\end{array}$ & $\begin{array}{l}2 \\
3\end{array}$ & $\begin{array}{l}\checkmark \\
9\end{array}$ & $\begin{array}{l} \\
4\end{array}$ & & $\begin{array}{l}\checkmark \\
1\end{array}$ & $\begin{array}{l} \\
1\end{array}$ & $\begin{array}{l} \\
4\end{array}$ & $\begin{array}{l} \\
9\end{array}$ & $\begin{array}{l}\checkmark \\
1\end{array}$ & $\begin{array}{l}5 \\
4\end{array}$ & $\begin{array}{l} \\
1\end{array}$ & $\begin{array}{l}\checkmark \\
1\end{array}$ & $\begin{array}{l}2 \\
3\end{array}$ & $\begin{array}{l} \\
1\end{array}$ & $\begin{array}{l} \\
4\end{array}$ & $\begin{array}{l} \\
5\end{array}$ & $\begin{array}{l} \\
2 \\
\end{array}$ & $\begin{array}{l}2 \\
6\end{array}$ \\
\hline $\begin{array}{c}\text { Sol de Primavera } \\
\text { Beto Guedes - } 1979\end{array}$ & $\begin{array}{l} \\
5\end{array}$ & $\begin{array}{l}2 \\
6\end{array}$ & $\begin{array}{l}\checkmark \\
4\end{array}$ & $\begin{array}{l}2 \\
6\end{array}$ & $\begin{array}{l} \\
1 \\
1\end{array}$ & $\begin{array}{l}2 \\
8\end{array}$ & $\begin{array}{l}\checkmark \\
4\end{array}$ & & $\begin{array}{l}\checkmark \\
1\end{array}$ & \begin{tabular}{l|l} 
\\
1
\end{tabular} & $\begin{array}{l} \\
5\end{array}$ & $\begin{array}{l} \\
7\end{array}$ & $\begin{array}{l}\checkmark \\
1\end{array}$ & $\begin{array}{l}\checkmark \\
5\end{array}$ & $\begin{array}{l} \\
1\end{array}$ & & $\begin{array}{l}2 \\
3\end{array}$ & $\begin{array}{l} \\
2\end{array}$ & $\begin{array}{l}2 \\
3\end{array}$ & \begin{tabular}{l|l} 
\\
2
\end{tabular} & $\begin{array}{l} \\
1\end{array}$ & $\begin{array}{l} \\
2\end{array}$ \\
\hline $\begin{array}{l}\text { Terra dos Pássaros } \\
\text { Toninho Horta - } 1979\end{array}$ & $\begin{array}{l}\checkmark \\
3\end{array}$ & $\begin{array}{l}2 \\
2\end{array}$ & $\begin{array}{l}2 \\
3\end{array}$ & $\begin{array}{l} \\
5\end{array}$ & $\begin{array}{l} \\
1\end{array}$ & 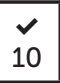 & $\begin{array}{l}\checkmark \\
4\end{array}$ & $\begin{array}{l}\checkmark \\
1\end{array}$ & & & $\begin{array}{l} \\
6\end{array}$ & $\begin{array}{c}\checkmark \\
10\end{array}$ & $\begin{array}{l}\checkmark \\
1\end{array}$ & $\begin{array}{l}2 \\
3\end{array}$ & $\begin{array}{l} \\
1\end{array}$ & & $\begin{array}{l}\checkmark \\
2\end{array}$ & $\begin{array}{l} \\
2\end{array}$ & $\begin{array}{l} \\
7\end{array}$ & \begin{tabular}{l|l} 
\\
1
\end{tabular} & $\begin{array}{l} \\
7 \\
\end{array}$ & $\begin{array}{l} \\
5\end{array}$ \\
\hline $\begin{array}{l}\text { Total de discos com } \\
\text { ocorrência } \rightarrow>\end{array}$ & & & & & & & & & & & & & & & & & & & & & & \\
\hline $\begin{array}{l}\text { Total de faixas com } \\
\text { ocorrência } \rightarrow>\end{array}$ & & & & & & & & & & 36 & & & & & & & & & & & & 0 \\
\hline
\end{tabular}

Tab. 2: Síntese do registro da ocorrência, em cada disco, dos elementos composicionais elencados na pesquisa

\section{Considerações acerca da utilização dos elementos composicio- nais do Clube da Esquina como recurso criativo no processo de elabo- ração de arranjos vocais}

A seguir, serão apresentados os resultados das experimentações realizadas no processo de criação musical de dois arranjos vocais presentes na pesquisa. É aqui que ocorre a "conversão" do processo analítico em processo criativo. Todo o conjunto de conhecimentos vislumbrados a partir das análises é sintetizado na forma de produções artísticas, constituídas em uma espécie de "laboratório" de reúso, recomposição e ressignificação dos elementos de estruturação musical que permeiam a escrita de arranjos vocais. 
Conforme já exposto no início, não foi objetivo do presente trabalho criar uma metodologia de escrita específica, com diretrizes fechadas e delimitadas a uma sonoridade particular. O conjunto de procedimentos e técnicas abordado em cada arranjo não se destina a cumprir função de "receituário" nem de "resgate de sonoridade". Buscou-se aqui vislumbrar as possibilidades de ordem artística que podem emergir como fruto da combinação entre as técnicas de escrita vocal já consagradas com os elementos composicionais explorados pelo Clube da Esquina. Os arranjos criados e apresentados tencionam demonstrar de forma prática algumas das perspectivas de aplicação dos "saberes e fazeres" inerentes às próprias produções musicais, apreendidos a partir de um olhar analítico. Os arranjos podem ser vistos aqui como um desdobramento de cunho teórico-reflexivo e ao mesmo tempo prático-inventivo, sem dicotomias. Ou seja, eles são uma forma de escuta crítica e de visão crítica acerca dos elementos teóricos que permeiam o próprio processo analítico e o próprio processo de criação.

Esses arranjos apresentam-se, em certa medida, como uma forma de expor e sintetizar os conhecimentos extraídos das análises utilizando-se não só da "escrita verbal", mas também da "escrita musical". Tal forma de registro possibilitou uma apropriação crítica do conteúdo teórico estudado. Embora o Clube da Esquina tenha sido aqui o objeto de estudo, esse mesmo princípio pode ser ampliado para outros contextos, com outros objetos, com outros conhecimentos frutos de outras análises, aplicados em diferentes processos de criação musical.

Os elementos composicionais do Clube da Esquina foram trabalhados de forma diversa ao longo da etapa de criação. Cada um desses arranjos produzidos na presente pesquisa apresenta um conjunto de experimentações particular. Como qualquer processo de experimentação, o trabalho foi permeado pelo "fazer e refazer" constante, onde várias combinações eram testadas e re-testadas, até o arranjo alcançar o resultado pretendido. Quanto ao foco, no que se refere aos parâmetros de estruturação musical manipulados, essas experimentações foram organizadas em quatros grandes grupos:

- experimentações quanto ao tratamento harmônico;

- experimentações quanto ao tratamento das interações rítmicas;

- experimentações quanto ao tratamento textural e timbrístico;

- experimentações quanto à estrutura formal.

Evidentemente, esses grupos se inter-relacionam. A manipulação de um parâmetro pode afetar outros de forma significativa. Cada um dos 22 elementos composicionais conecta-se mais diretamente a um desses grupos. Contudo, as experimentações concretizaram-se de forma integrada nos arranjos, sem linhas divisórias ou hierárquicas quanto à valoração de um ou outro parâmetro trabalhado. Embora a maioria dos elementos elencados conecte-se mais diretamente às experimentações quanto ao tratamento harmônico (em especial às rearmonizações), não significa que as experimentações que tangem aos demais parâmetros tenham cumprido papel secundário, pelo contrário, todas as questões que envolveram o tratamento rítmico, textural, timbrístico e formal foram fundamentais no processo de criação dos arranjos.

Em cada um deles utilizou-se um conjunto de elementos composicionais diferente, de acordo com os propósitos de sonoridade que se pretendeu alcançar. Não signi- 
fica que esses elementos permearam tudo, o tempo todo. Foram implementados de modo diversificado, seja para modificar a macroestrutura, seja para manipular apenas um trecho específico. Mesclaram-se tanto de forma simultânea como assíncrona.

Tais experimentações também foram balizadas pelos princípios básicos de escrita para vozes, assim como pelas técnicas de caráter homofônico e polifônico comumente utilizadas em arranjos vocais na prática da música popular. Assim, podemos sintetizar os conteúdos e procedimentos explorados nos arranjos, quanto ao foco de manipulação dos parâmetros de estruturação musical, conforme ilustrado na Fig. 1.

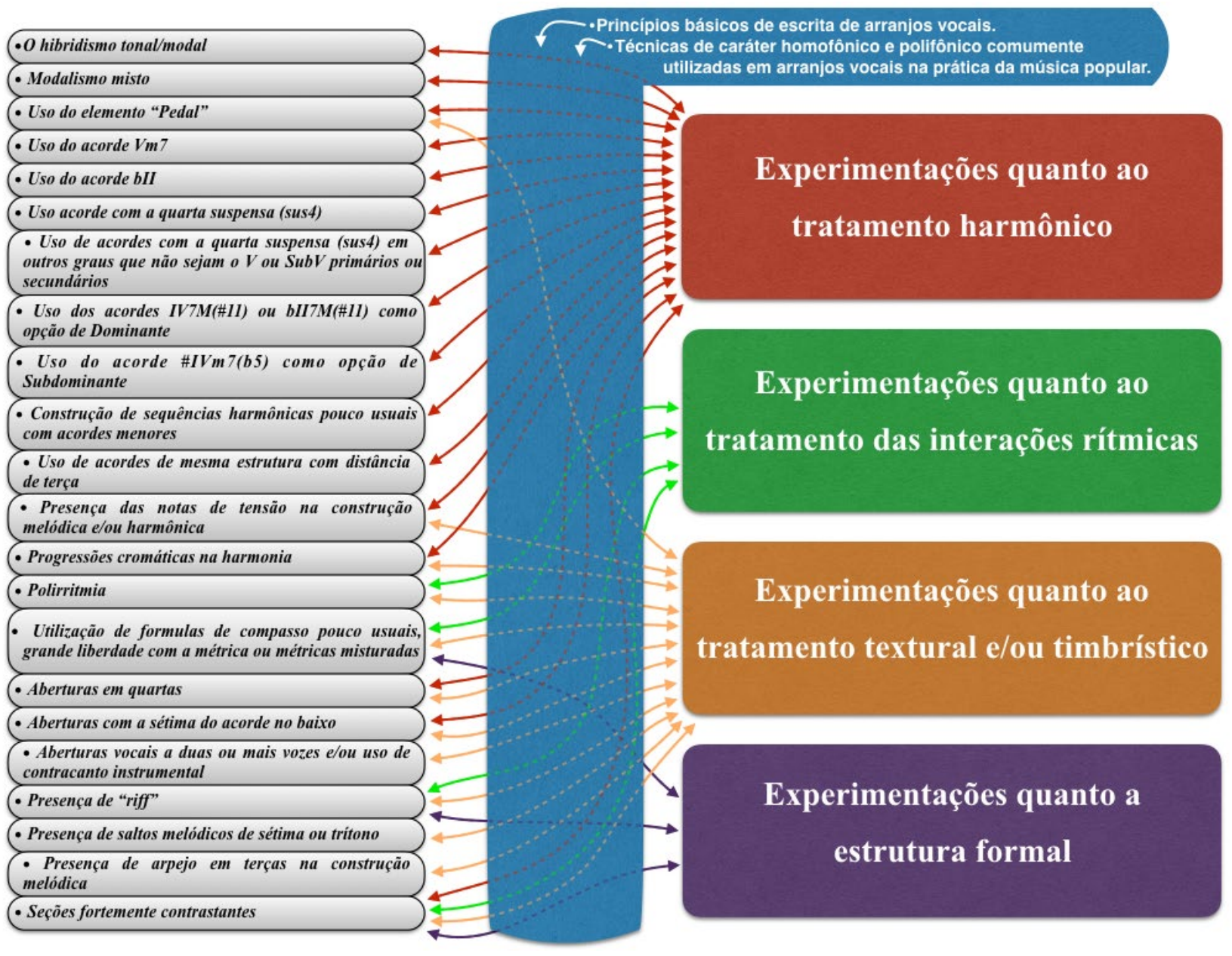

Fig. 1: Síntese em forma de diagramas de como os elementos composicionais do Clube da Esquina conectam-se com as experimentações que permearam o processo de elaboração dos arranjos vocais

\section{O arranjo da canção Milagre dos Peixes, de Milton Nascimento e Fernando Brant (para coro misto à capela)}

A canção Milagre dos Peixes (Milton Nascimento e Fernando Brant) dá nome ao disco que Milton gravou em 1973. Essa canção sintetiza bem a concepção artística do disco, tanto no conteúdo da letra quanto no musical, pois, além da crítica à ditadura militar, o álbum também reflete o "esforço de se produzir uma obra inovadora em meio 
ao crescimento e consolidação capitalista e da indústria fonográfica, cada vez mais eficiente em seus ditames quantitativos e de homogeneização" (DINIZ, 2012, p.123). A análise detalhada dessa canção é apresentada na tese. Por ser extensa, optou-se por não apresentá-la aqui, apenas uma breve síntese da estrutura formal (Fig. 2), seguida da partitura do arranjo vocal (Fig. 3) e da descrição de como os elementos composicionais foram utilizados no processo de criação.

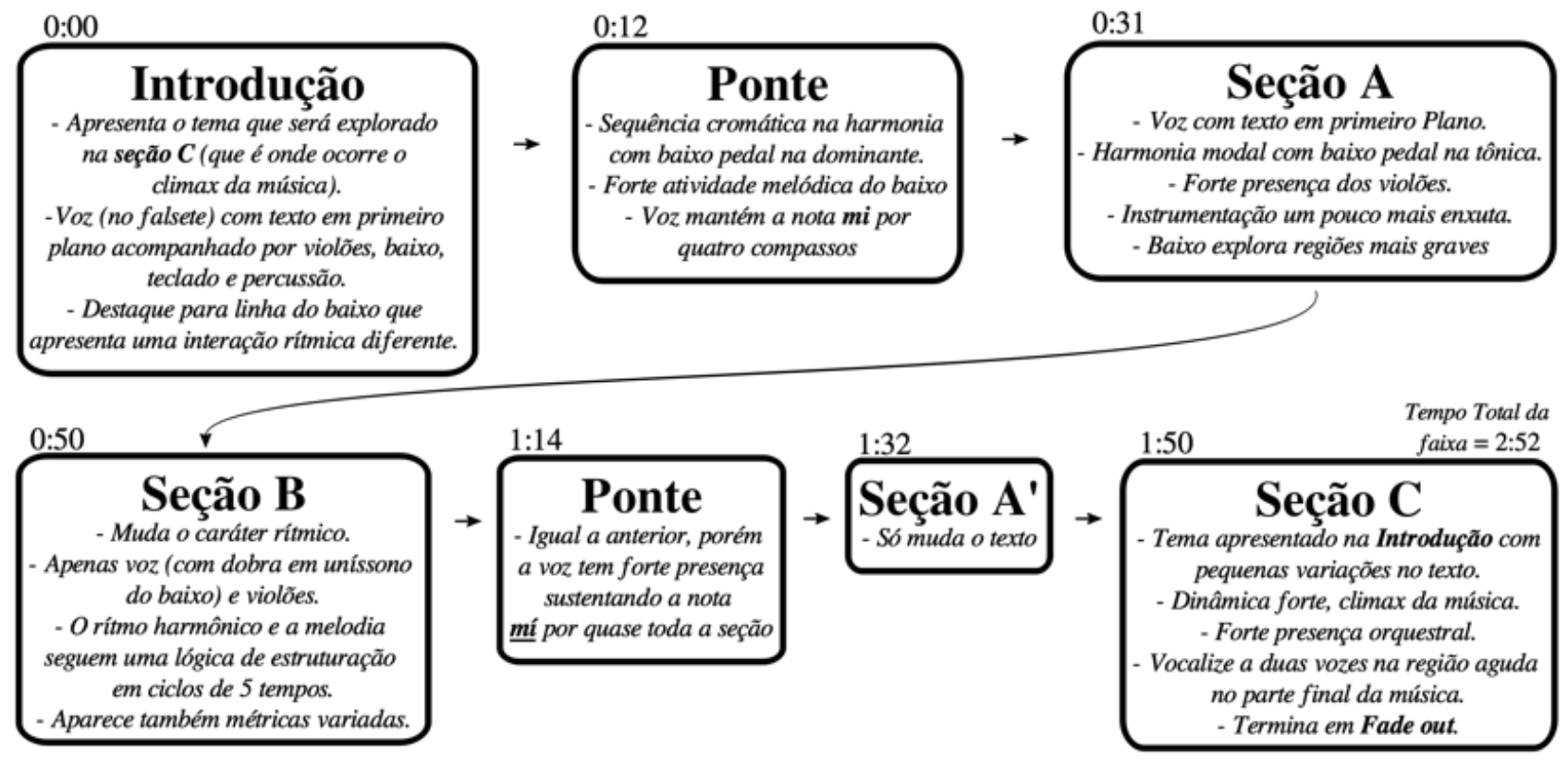

Fig. 2: Estrutura geral do fonograma Milagre dos Peixes, de Milton Nascimento e Fernando Brant, com a marcação do posicionamento do início de cada seção na faixa do disco (min:seg)

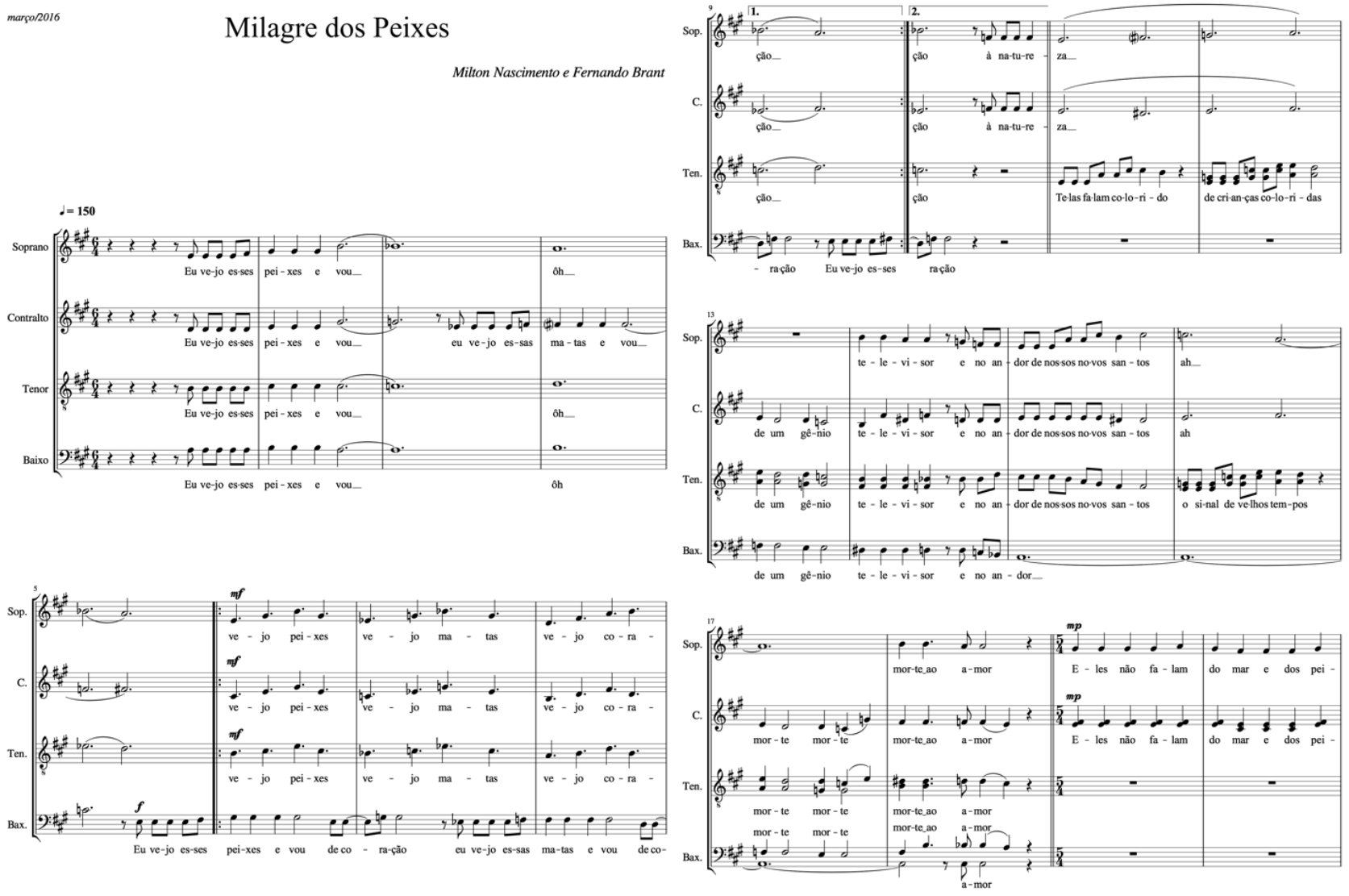



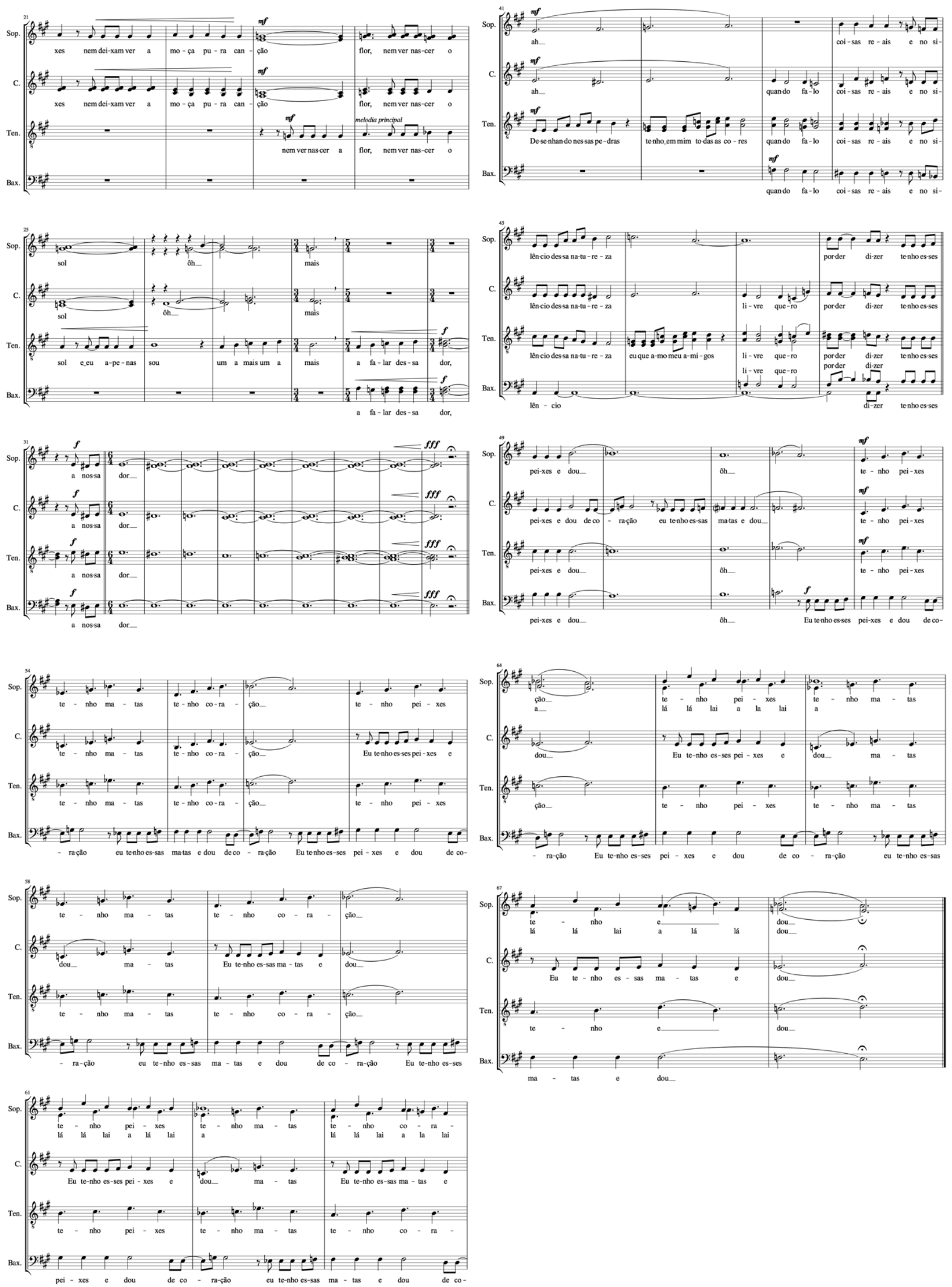

Fig. 3: Arranjo vocal da canção Milagre dos Peixes, de Milton Nascimento e Fernando Brant, para coro misto à capela (arranjo de Carlos R. F. Menezes Jr.) 
Na versão original, a tessitura melódica é grande, de duas oitavas e uma segunda menor (somando-se a melodia principal e os vocalises finais). No arranjo, que foi concebido para coro misto à capela, a tessitura geral vai do lá 1 ao mi 4 . A tessitura de cada voz é apresentada na Fig. 4.

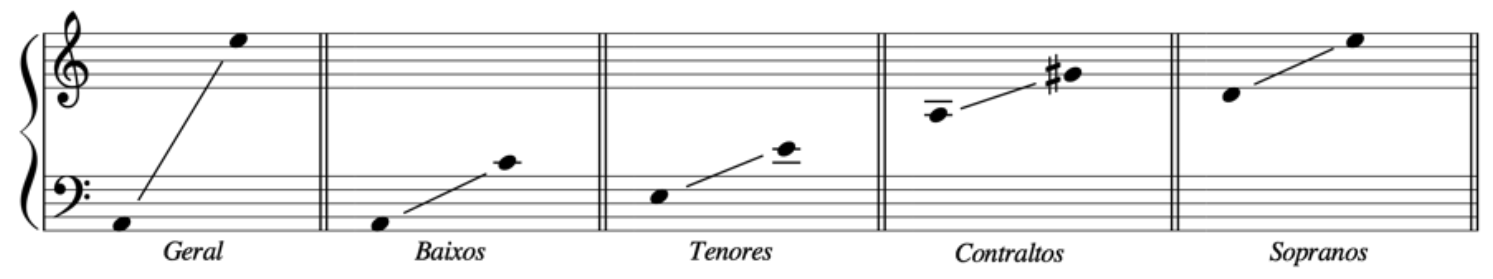

Fig. 4: Tessituras das vozes no arranjo da canção Milagre dos Peixes

A maioria dos elementos composicionais elencados na análise da canção também foram utilizados no arranjo, tais como: hibridismo tonal/modal; modalismo misto; uso do elemento "pedal"; uso do acorde Vm7; uso do acorde bll; uso de acorde com a quarta suspensa (sus4); uso do acorde bll7M(\#11) como opção de Dominante; acordes de mesma estrutura com distância de terça; presença das notas de tensão na construção harmônica; acordes com a sétima no baixo; progressões cromáticas na harmonia; polirritmia; seções fortemente contrastantes; métricas misturadas. É importante salientar que se optou por não fazer a análise da relação letra e música, pois demandaria uma ampliação do escopo do trabalho e poderia acarretar no desvio do foco proposto na pesquisa.

Outros elementos composicionais presentes no repertório do Clube da Esquina também foram explorados no arranjo visando reestruturar alguns trechos ou enfatizar algumas das peculiaridades da canção, são eles: acordes menores em cromatismo descendente; arpejos melódicos em terças; uso de saltos melódicos dissonantes (tais como trítono e segunda aumentada); uso significativo de aberturas em segundas; forte presença de paralelismos envolvendo intervalos de quinta justa, quarta justa, oitava, sétimas e segundas; cruzamento de vozes.

A estrutura geral sofreu algumas modificações em relação à versão original. A introdução foi expandida, e a primeira ponte foi suprimida. Essa decisão foi tomada visando explorar mais as possibilidades texturais que a linha da introdução oferecia, pois tal exploração também seria retomada e expandida no final do arranjo. Além disso, julgou-se que, ao suprimir a ponte da parte inicial, o seu aparecimento no meio da música teria mais impacto (isso será esmiuçado logo adiante). As demais seções foram mantidas, porém com algumas modificações, principalmente no que se refere à harmonia. É na segunda ponte que ocorreu a modificação mais significativa. A sequência de acordes maiores deslocando-se cromaticamente no sentido descendente foi substituída por um grande cluster construído a partir de uma linha cromática descendente que começa em uníssono e perpassa os naipes dos sopranos, contraltos e tenores. O detalhamento de como a textura foi trabalhada nessa e nas demais seções será abordado mais adiante. Assim, a estrutura geral do arranjo ficou como apresentada na Fig. 5. 


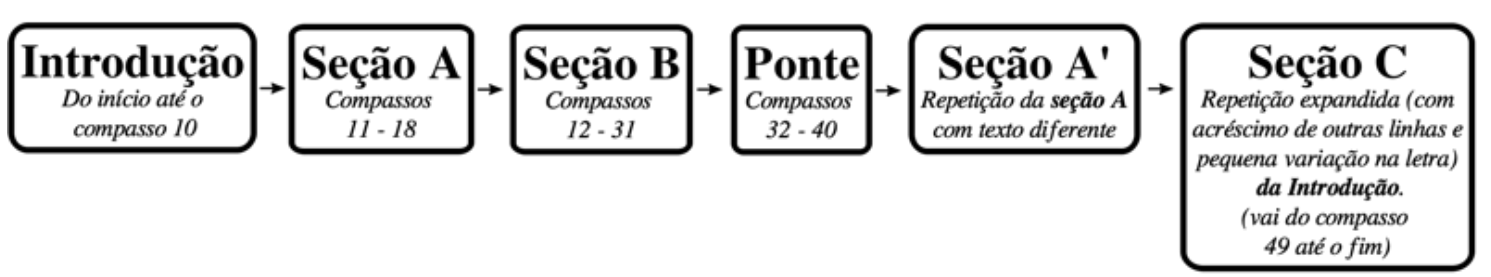

Fig. 5: Estrutura formal do arranjo vocal da canção Milagre dos Peixes

A rearmonização foi trabalhada na introdução (e consequentemente na seção C, que é a repetição expandida da introdução com acréscimo de outras linhas e pequena variação na letra), na seção B e na ponte. A Fig. 6 mostra a comparação entre a harmonia original e a rearmonização que ocorreu na introdução.

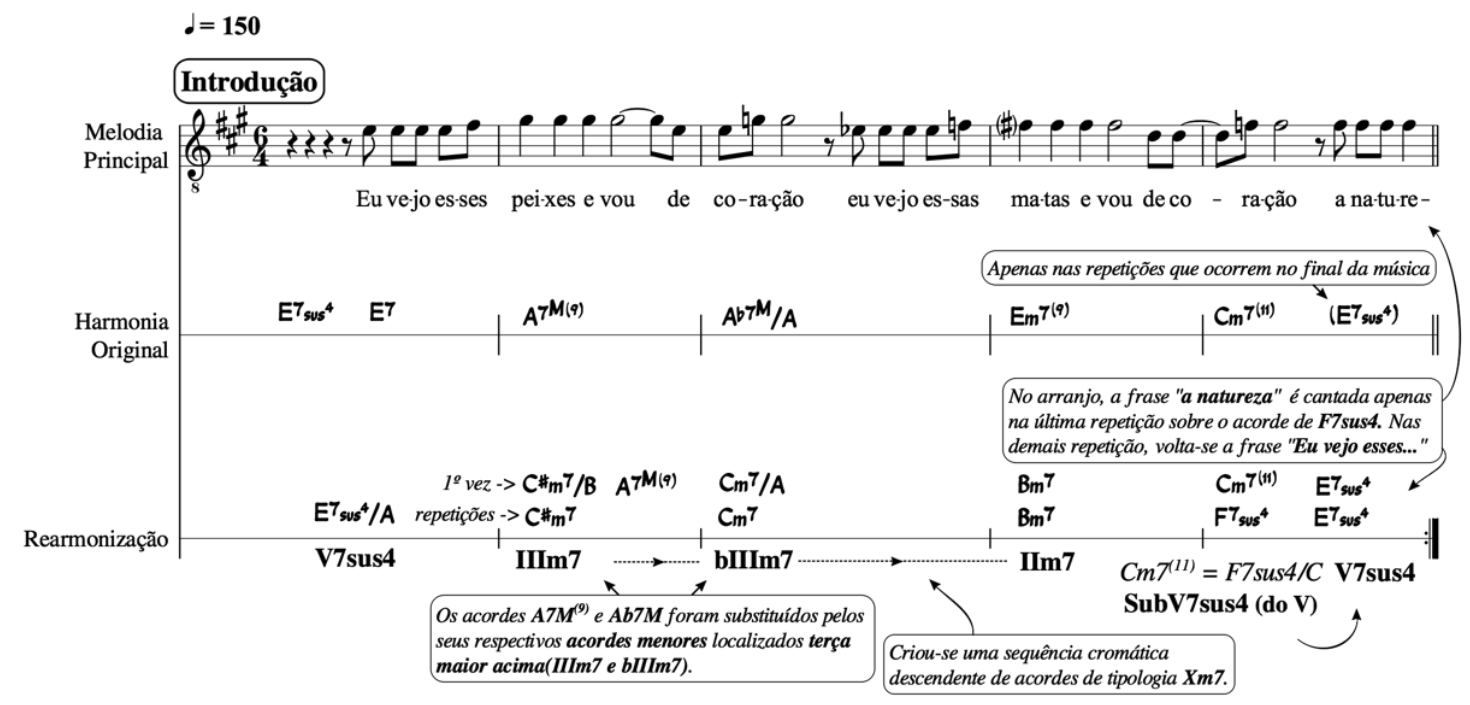

Fig. 6: Harmonia original e rearmonização na introdução do arranjo vocal da canção Milagre dos Peixes

A principal mudança harmônica nessa seção ocorreu com a substituição dos acordes de tipologia maior com sétima maior (X7M) por acordes menores com sétima menor (Xm7) localizados uma terça maior acima, ou seja, por acordes menores contidos no interior da escala dos respectivos acordes maiores. No caso do $E m 7^{(9)}$, partindo-se da ideia de interpretá-lo também como um $\mathrm{G} \mathrm{M}^{(6)} / \mathrm{E}$, sua substituição pelo $\mathrm{Bm} 7$ segue a mesma lógica. Como resultado, criou-se uma sequência cromática descendente de acordes menores, algo presente em outras canções do próprio repertório do Clube da Esquina, como, por exemplo, a primeira parte da composição Vera Cruz, de Milton Nascimento e Márcio Borges, lançada em 1969 no disco Courage. Quanto à substituição do $\mathrm{Cm}^{(11)}$ pelo F7sus4, bastou mudar a disposição das notas entre as quatro vozes, colocando o fá no baixo, para que se efetivasse, pois o $\mathrm{Cm}^{(11)}$ é igual ao F7sus4/C.

Na seção $B$, a harmonia dos três primeiros compassos foi estruturada a partir de clusters em blocos a três vozes (apenas com timbres femininos) com as notas da escala de acorde de A7M. As demais mudanças harmônicas presentes nessa seção estão indicadas na Fig. 7. 

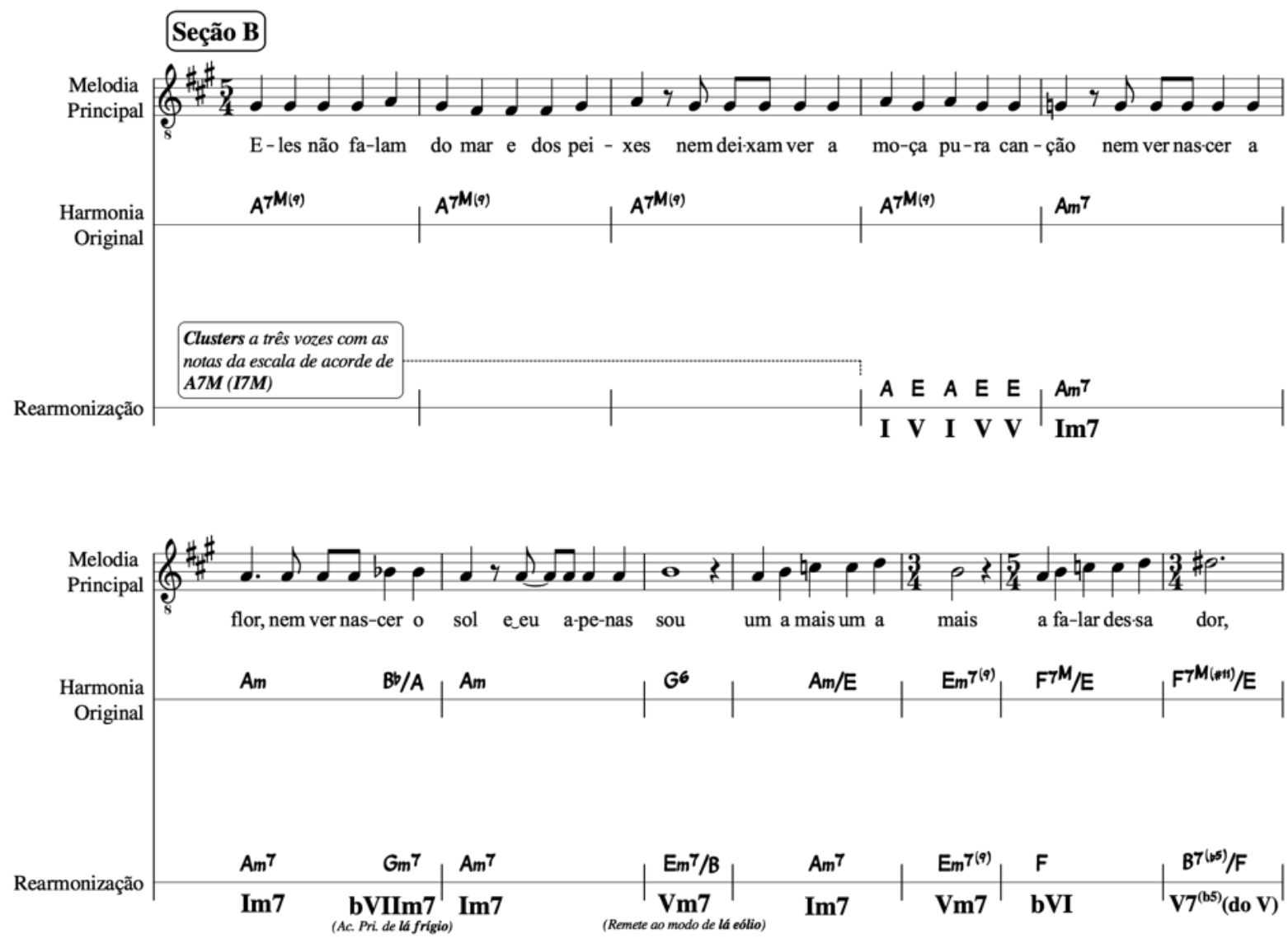

Fig. 7: Harmonia original e rearmonização na seção B do arranjo vocal da canção Milagre dos Peixes

Quanto à textura trabalhada nas vozes, combinaram-se as seguintes técnicas de escrita: técnicas mecânicas de escrita em bloco na posição cerrada ${ }^{6}$ (GUEST, 1996); aberturas em segundas (também denominadas de estruturas supercerradas ou clusters); cama harmônica; contracanto de caráter ativo7; contracanto harmonizado em bloco. Cada seção recebeu um tratamento específico.

Nos cinco primeiros compassos da introdução, combinou-se escrita em bloco com cama harmônica. As frases "Eu vejo esses peixes e vou de coração" e "Eu vejo essas matas e vou de coração" foram apresentadas parcialmente, sem o final "de coração", resultando nas frases "Eu vejo esses peixes e vou" e "Eu vejo essas matas e vou". A primeira frase foi estruturada em blocos, começando com aberturas em segundas e terminando com técnicas mecânicas. A segunda frase foi estruturada com textura de melodia acompanhada por cama harmônica. A intenção de omitir o trecho "de coração" foi jus-

\footnotetext{
6 As técnicas mecânicas em bloco são tratadas por Guest (1996) como uma forma de escrita que segue uma lógica de construção às quais as linhas melódicas surgem como consequência de um "pensamento vertical". Consiste em atribuir à voz mais aguda a melodia principal e ir completando (harmonizando), em cada nota da melodia, com as notas do acorde, distribuindo-as de cima para baixo de forma que resulte em uma estrutura cerrada (ou posição fechada) entre a primeira e a última voz, ou em aberturas específicas (denominadas de Drop 2, Drop 3 e Drop 2+4). As minúcias de tal técnica de escrita são apresentadas por Guest (1996) no segundo volume de seu método prático.

7 Guest (1996) aborda os contracantos ativo e passivo no item em que discute técnicas de escrita a duas vozes. A diferença entre ativo e passivo é apresentada a partir do grau de movimentação melódica e, consequentemente, da inter-relação que se estabelece com o ritmo harmônico e com a melodia principal. 0 contracanto ativo é mais livre e movimentado, enquanto o contracanto passivo apresenta alto grau de dependência do ritmo da harmonia e, com isso, menos movimentado.
} 
tamente para ajudar a dar mais ênfase à cama harmônica e gerar maior contraste em relação à segunda parte da introdução, na qual esse fragmento da letra retorna no naipe dos baixos. Movimentos paralelos e diretos foram muito explorados nesse trecho, assim como nas demais seções do arranjo, conforme ilustra a Fig. 8. A intenção que balizou tal escolha foi a de propiciar uma sonoridade de "bloco harmônico" mais coeso e compacto, articulando-o com outras linhas melódicas que vão surgindo "fora do bloco", resultando em sobreposições de planos sonoros mais contrastantes.

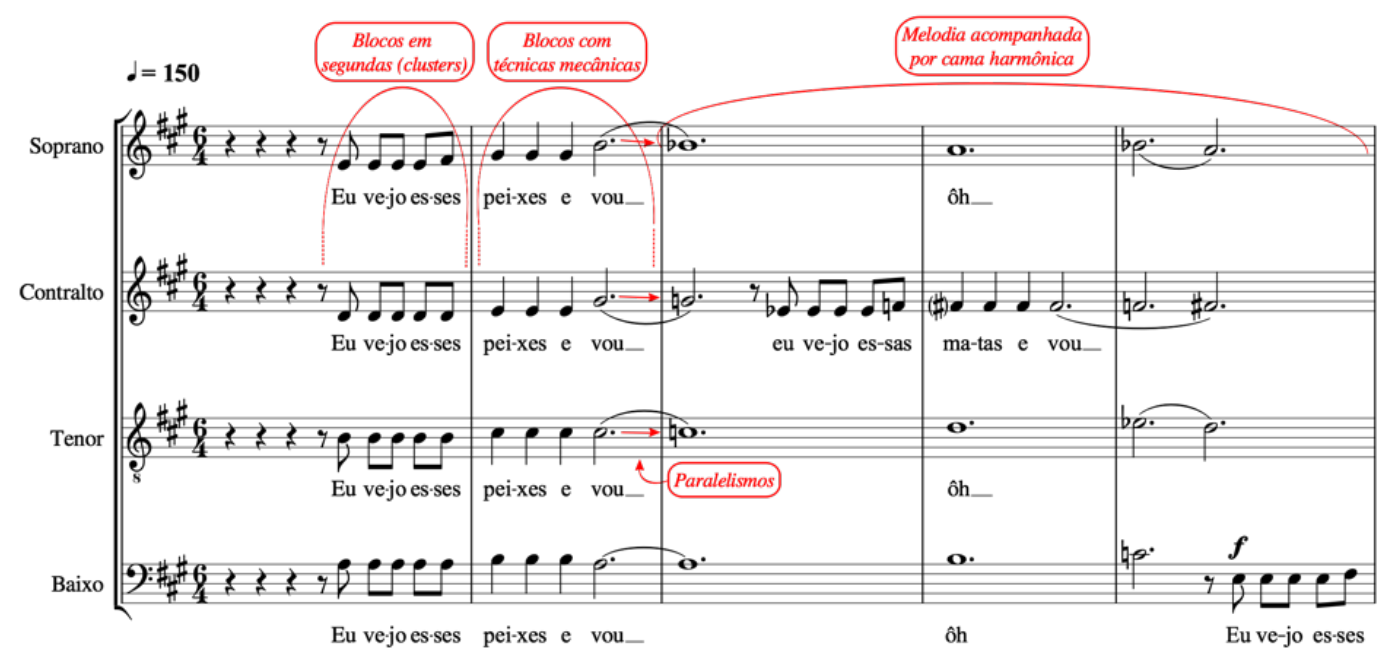

Fig. 8: Primeira parte da introdução do arranjo vocal da canção Milagre dos Peixes

Na segunda parte da introdução (Fig. 9), tem-se a melodia principal no naipe dos baixos acompanhada por um contracanto estruturado por arpejos melódicos em terças, harmonizado em bloco na posição cerrada. O ritmo do contracanto foi construído a partir da mesma lógica apresentada pelo baixo elétrico na versão original, ou seja, marcando quatro tempos simétricos por compasso, em oposição à lógica de seis tempos explicitada pela melodia principal. Essa interação rítmica remete ao efeito de polirritmia.

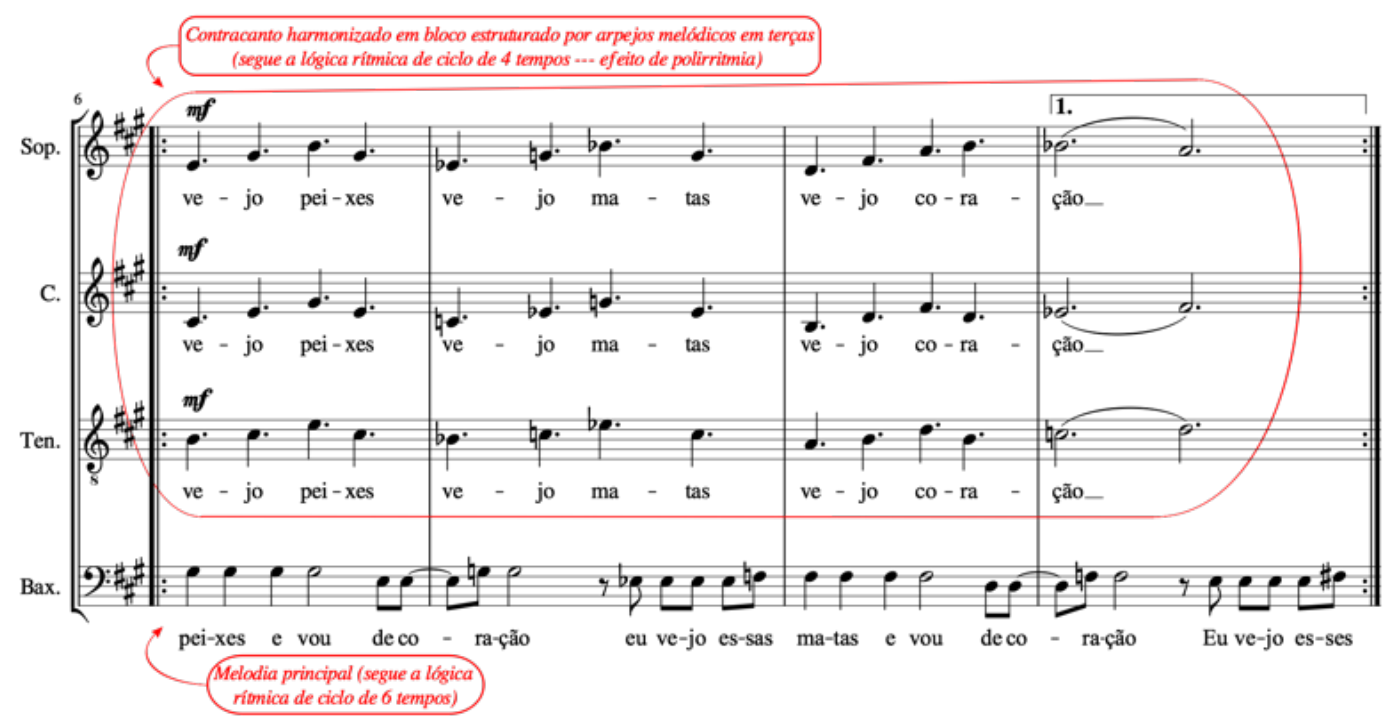

Fig. 9: Segunda parte da introdução do arranjo vocal da canção Milagre dos Peixes 
Conclui-se a introdução com a frase "à natureza" em uníssono nas vozes femininas. Essa frase também cumpre a função de ligar o final da introdução com o início da seção A. Os naipes dos contraltos e sopranos continuam com um contracanto de caráter passivo a duas vozes durante os compassos 11 e 12, enquanto o naipe dos tenores canta a melodia principal que começa em uníssono e depois se abre a duas vozes em bloco. Nos compassos 13 e 14, a textura geral é de escrita em bloco (técnicas mecânicas). Os próximos quatro compassos seguem a mesma escrita apresentada nos compassos 11 até 14, porém com o acréscimo do baixo pedal em lá (pedal na tônica).

A seção B (Fig. 10) começa apenas com os timbres femininos em bloco a três vozes com aberturas em segundas, utilizando-se das notas da escala de acorde de A7M (I7M). Optou-se por esse tipo de escrita nesse trecho por propiciar uma sonoridade dissonante e ao mesmo tempo leve e coesa. Aos poucos as vozes vão se abrindo e a textura vai ficando mais cheia, com sonoridade mais densa ao longo da seção. A partir do compasso 22 , volta-se a utilizar as técnicas mecânicas, e o arranjo segue alternando-se entre escrita em bloco e cama harmônica até o final da seção (explorando-se, também, os timbres dos demais naipes).

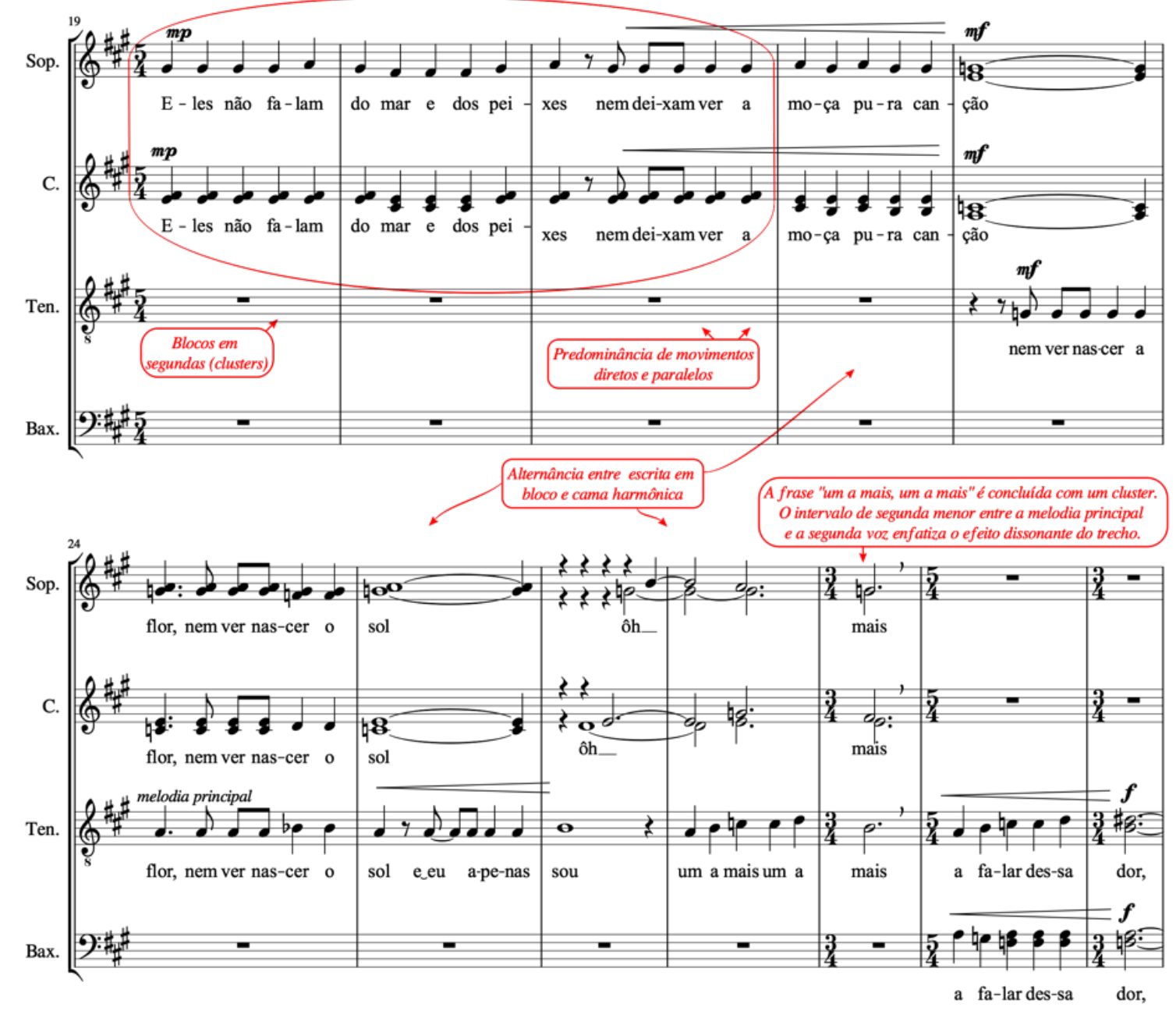

Fig. 10: Seção B do arranjo vocal da canção Milagre dos Peixes 
Na ponte, que na gravação original apresenta grande ênfase na palavra "dor", prolongando-a (na voz de Milton Nascimento) por sete compassos enquanto a harmonia vai caminhando cromaticamente no sentido descendente, explorou-se a ideia de utilizar um cluster a sete vozes estruturado por segundas menores adjacentes como forma de enfatizar e tensionar a palavra "dor" (Fig. 11). A intenção aqui foi propiciar um forte destaque à "dor" por meio de uma massa sonora intensa e dissonante, construída a partir da ideia de cromatismo (sugerida pela harmonia da própria canção). Esse cluster é construído gradativamente a partir do movimento cromático descendente das vozes (que se dividem ao longo da seção). Assim como na gravação original, o baixo em mi foi utilizado como elemento pedal. Logo após o cluster vem uma pausa com fermata. 0 silêncio cumpre a função de elemento de contraste, intensificando o efeito de "tensão" explorado no final dessa seção.

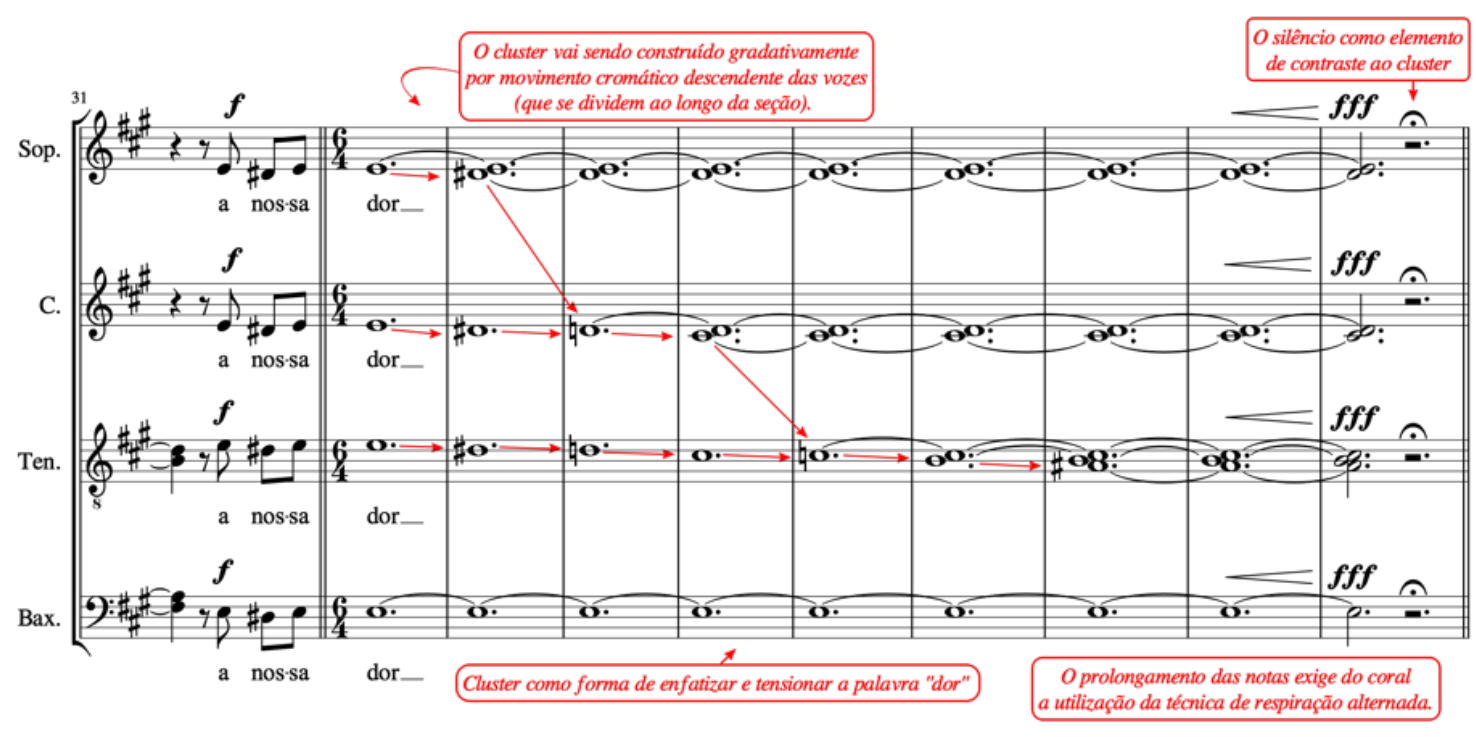

Fig. 11: Cluster presente na ponte no arranjo vocal da canção Milagre dos Peixes

Logo após a ponte, vem a seção A', que é a repetição da seção A com texto diferente. $O$ tratamento dado às vozes é o mesmo.

Em seguida vem a seção $C$, que é a repetição do material apresentado na introdução, porém com alguns elementos novos e com uma pequena variação na letra. As frases "Eu vejo esses peixes e vou de coração" e "Eu vejo essas matas e vou de coração" são substituídas por "Eu tenho esses peixes e dou de coração" e "Eu tenho essas matas e dou de coração" (assim como na gravação original). A escrita das vozes nos compassos 49 ao 56 é exatamente igual à introdução. A partir do 57, os contraltos passam a cantar um contracanto de caráter imitativo em relação à melodia principal enquanto as demais vozes seguem repetindo as mesmas melodias. A partir do compasso 61 (Fig. 12), aparece uma quinta voz no naipe dos sopranos, estruturada a partir da ideia apresentada pela linha dos violoncelos na gravação original. Esse contracanto na região aguda, com forte marcação rítmica da subdivisão do compasso em seis tempos simétricos, enfatiza o contraste em relação ao tratamento rítmico dado ao contracanto harmonizado em bloco presente nas outras vozes, que segue marcando a subdivisão do compasso em 
quatro tempos simétricos. O cruzamento de vozes que ocorre entre as melodias do naipe das sopranos propicia um efeito que remete à ideia de "fusão" entre linhas contrastantes, procedimento explorado por Milton nos vocalises finais da gravação original.
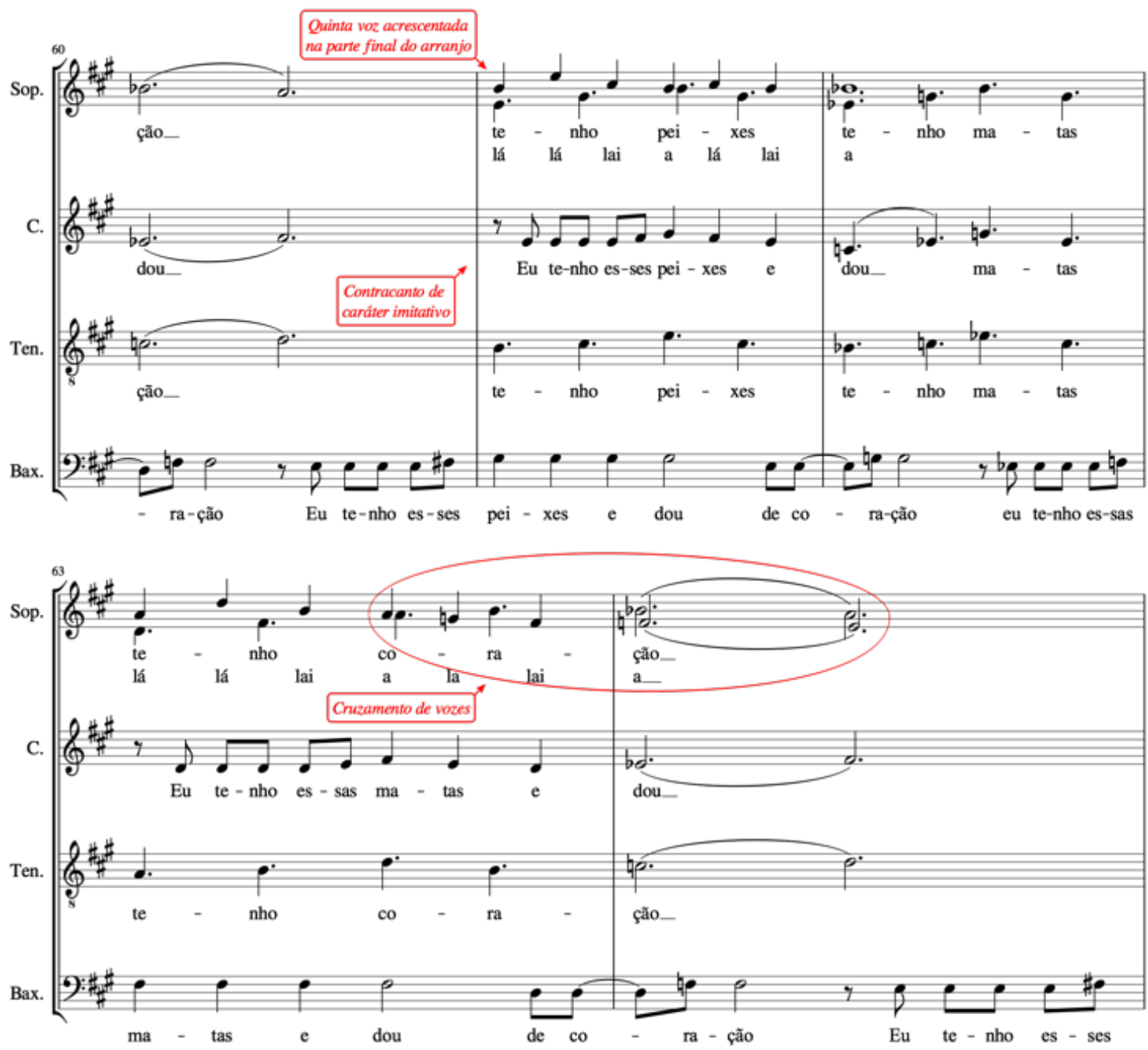

Fig. 12: Trecho da seção C do arranjo vocal da canção Milagre dos Peixes

O arranjo termina no acorde de dominante com a quarta suspensa (E7sus4) sem resolver na tônica.

A decisão de trabalhar com o cruzamento de vozes na parte final, assim como de explorar os arpejos de acordes menores nas vozes superiores com o ritmo que subdivide o compasso em quatro partes iguais e usar mais intensamente as aberturas em segundas, veio a partir da ideia de enfatizar os próprios elementos composicionais explorados pelo Clube da Esquina. Assim, optou-se por condensá-los e misturá-los, em uma brincadeira ao mesmo tempo formal e criativa, em busca de uma sonoridade mais complexa e contrastante, evidenciada pelo uso das interações rítmicas e transformações harmônicas. 


\section{O arranjo da canção Chovendo na Roseira, de Tom Jobim (para trio vocal feminino e violão)}

A canção Chovendo na Roseira, de Tom Jobim, foi composta, a princípio, como tema instrumental intitulado Children's Game, lançado no disco Stone Flower em 1970. Nesse ano, Tom Jobim gravou dois discos simultaneamente, o Stone Flower e o Tide, ambos com arranjos de Eumir Deodato. A música Children's Game fez parte da trilha sonora do filme americano The Adventures (1970). Posteriormente recebeu letra do próprio Tom Jobim e foi lançada como Chovendo na Roseira, no antológico disco Elis e Tom de 1974. A Fig. 13 apresenta a partitura no formato de lead sheet, ${ }^{8}$ editada a partir do manuscrito da versão de 1970 escrito por Eumir Deodato, disponível no site Instituto Antônio Carlos Jobim. As cifras estão representadas da mesma forma que aparecem no manuscrito. Logo em seguida, a Fig. 14 apresenta a partitura do arranjo vocal.

\section{Children's Game}

\section{(Chovendo na Roseira)}

Antônio Carlos Jobim Arr. by Eumir Deodato
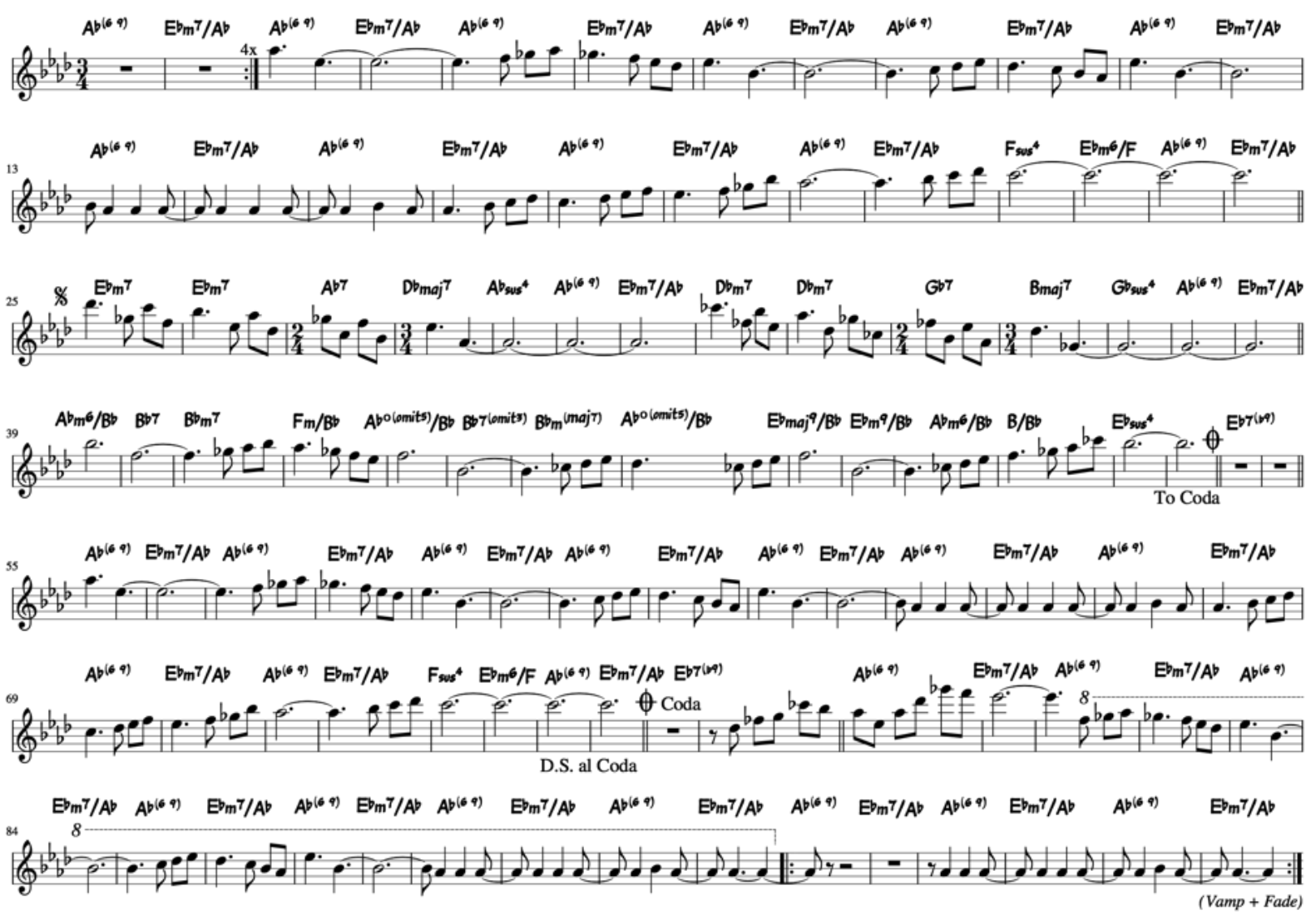

Fig. 13: Partitura no formato lead sheet editada a partir do manuscrito de Eumir Deodato, feito para a primeira gravação do tema instrumental Children's Game de 1970 (posteriormente transformado na canção Chovendo na Roseira). Fonte: Instituto Tom Jobim.

8

O termo lead sheet é muito utilizado no universo da música popular para designar um tipo de registro de partitura em que apenas as informações essenciais de uma obra são apresentadas, tais como linha melódica principal, acordes na forma de cifra e, no caso de canções, a letra. Eventualmente o detalhamento de alguns acompanhamentos instrumentais também é registrado. É a forma mais comum de escrita contida nos chamados soongbooks. 

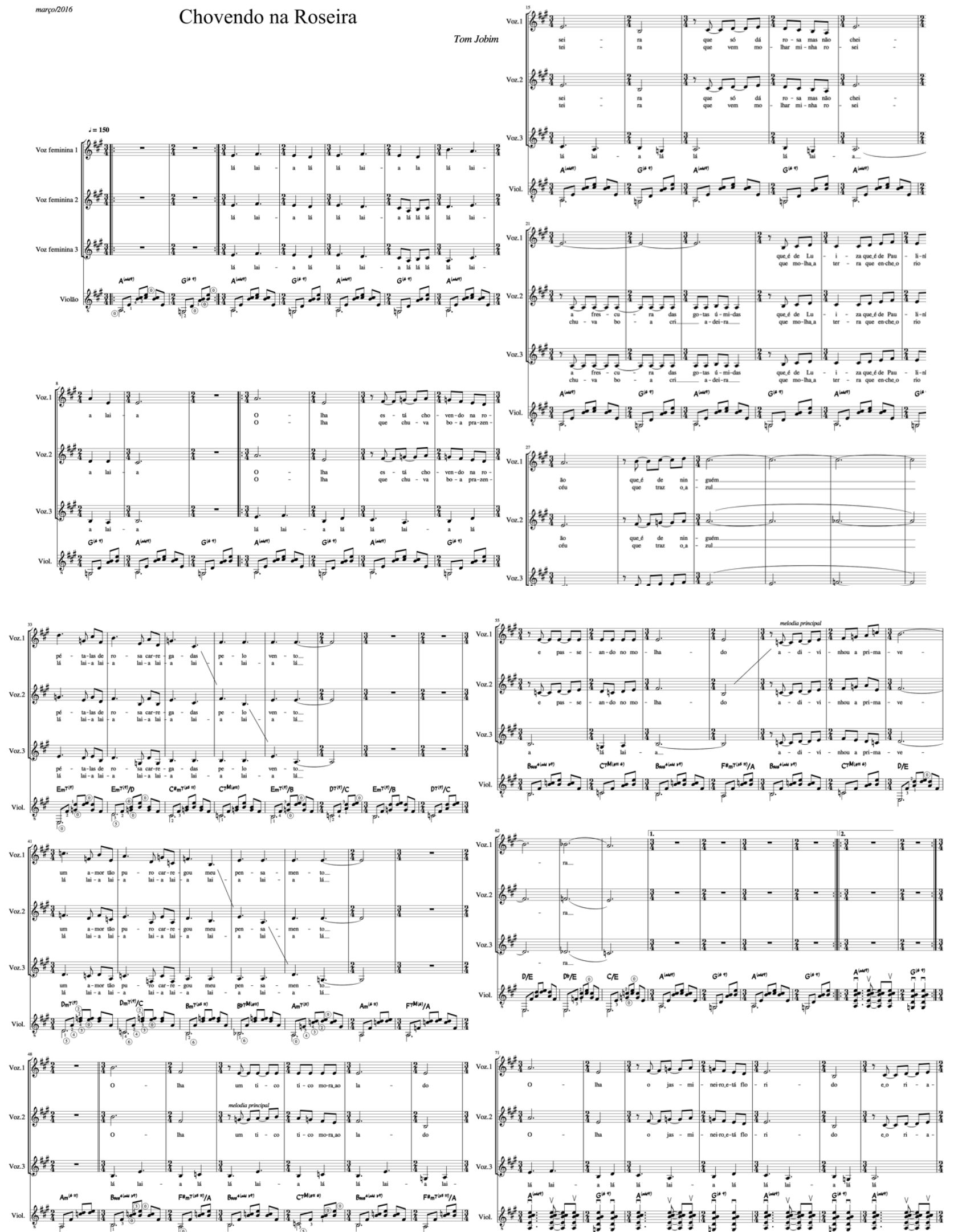

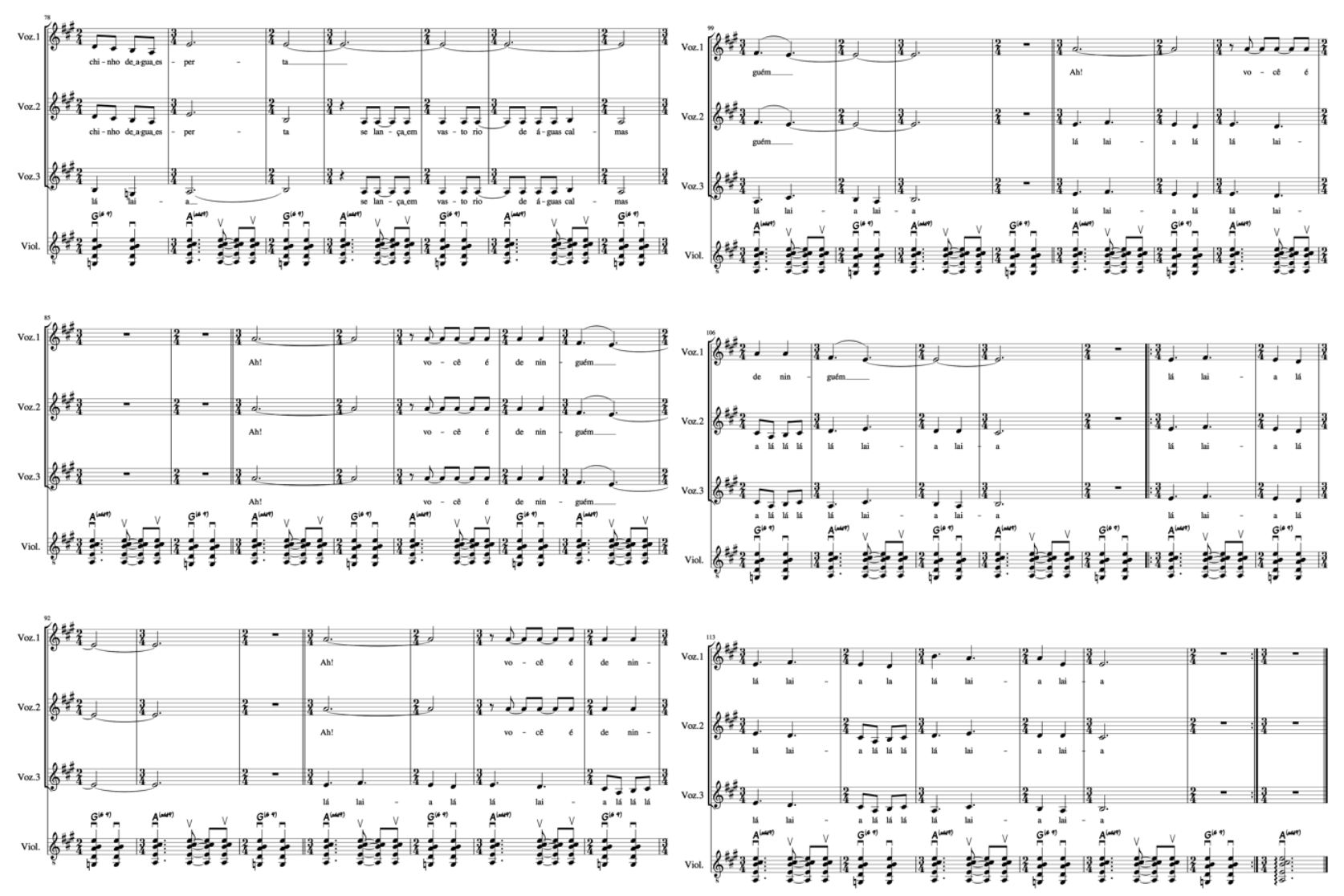

Fig. 14: Arranjo da canção Chovendo na Roseira, de Tom Jobim, para trio vocal feminino e violão (arranjo de Carlos R. F. Menezes Jr.)

Nesse arranjo, concebido para trio vocal feminino e violão, buscou-se trabalhar a harmonia e as interações rítmicas de forma a criar uma sonoridade geral mais ligada ao universo modal. Esse termo, embora muito utilizado no campo da teoria musical, pode remeter a concepções variadas. Sérgio Freitas, em seu artigo intitulado “Dos modos em seus mundos: usos do termo modal na teoria musical", ${ }^{9}$ propõe uma ordenação do termo modal em oito campos de entendimento.

O fato é que, quando definidos apenas pelas arrumações internas de seus intervalos, os modos dizem bem pouco sobre música, seja a pré-tonal europeia ou a popular do mundo atual. A diferença modal (como a tonal) não cabe na pura arrumação da escala, é preciso olhar o modo em seu mundo. (FREITAS, 2008, p.450-451).

Assim, a ideia de Freitas (2008) de ordenar em oito campos visa contextualizar a utilização do termo modal em oito "mundos" permeados pelas suas especificidades históricas e culturais. Não cabe aqui detalhar esses "mundos", que vão desde o sistema musical da antiguidade grega, passam pelo universo pré-tonal, tonal e pós-tonal e vão até as músicas populares atuais em suas mais diversas vertentes. $O$ termo "universo modal", adotado na presente pesquisa, está diretamente relacionado com o oitavo campo 
de entendimento abordado por Freitas (2008), que se localiza justamente na interface dos estudos étnicos aliados aos estudos na área de música popular. Ele engloba várias vertentes de pesquisas, que vão desde músicas modais do interior do nordeste brasileiro até as práticas modais populares norte-americanas, entre elas o modal jazz.

A canção Chovendo na Roseira está conectada a esse universo, assim como o repertório do Clube da Esquina. A ideia foi justamente utilizar os conhecimentos apreendidos durante a pesquisa para enfatizar e expandir alguns aspectos modais presentes na referida canção.

Os seguintes elementos composicionais elencados na presente pesquisa foram explorados no processo de criação do arranjo: modalismo misto; uso do elemento "pedal"; uso do acorde Vm7; uso do acorde bll; uso de acorde com a quarta suspensa (sus4); presença das notas de tensão na construção harmônica e melódica; acordes com a sétima no baixo; progressões cromáticas na harmonia; utilização de métricas misturadas; presença de riff instrumental.

A melodia principal apresenta tessitura melódica de uma oitava e uma quinta justa. No arranjo, a tessitura geral vai do fá 2 ao ré 4 . Ele foi escrito para as três vozes femininas do quarteto vocal VagaMundo, de Uberlândia (MG), do qual faço parte há, aproximadamente, 23 anos. A tessitura de cada linha melódica é apresentada na Fig. 15.

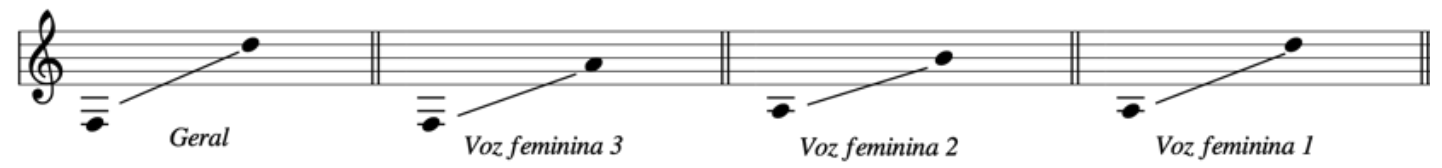

Fig. 15: Tessituras das linhas melódicas no arranjo da canção Chovendo na Roseira

Logo no início, os quatro principais elementos composicionais trabalhados ao longo do arranjo são apresentados, são eles: rearmonização com ênfase na sonoridade modal; riff do violão como principal base de sustentação rítmica/harmônica; métrica alternada entre compassos de três e dois tempos, resultando em uma espécie de ciclo assimétrico de cinco tempos; uso intensivo das cordas soltas mi (1ํ) e si (2) do violão como elemento pedal.

Segundo o pesquisador Sérgio Molina (2014, p.43), ${ }^{10}$ "As conduções rítmicas na música popular urbana das Américas baseiam-se muito mais em características herdadas da música da África subsaariana do que nos princípios que regem a rítmica da música clássica europeia". O autor também aponta as diferenças entre a ideia de tempo assentado na circularidade (lógica modal) e tempo assentado na linearidade (lógica tonal). Segundo ele, a sofisticação rítmica da música popular no Brasil reside justamente na fricção constante de dois diferentes princípios rítmicos, um de ordem circular e assimétrico (ligado às práticas modais da música africana) e outro de ordem linear e simétrico (ligado à música de concerto europeia de caráter tonal). Resultaram disso algumas práticas polirrítmicas e algumas estruturas de combinações de compassos mistos e assimétricos. Tais interações rítmicas estão muito presentes no repertório do

10 MOLINA, Sérgio. A composição de música popular cantada: a construção de sonoridades e a montagem dos álbuns no pós-década de 1960. 2014. 152 f. Tese (Doutorado em Música) - Universidade de São Paulo, São Paulo, 2014. 
Clube da Esquina, como, por exemplo, as canções: Maria Três Filhos (de Milton Nascimento e Fernando Brant, presente no disco Milton, de 1970); Meu Canário Vizinho Azul (de Toninho Horta, presente no disco de 1973); Amigo, Amiga (de Milton Nascimento e Ronaldo Bastos, presente no disco Milton, de 1970); Luz e Mistério (de Beto Guedes e Caetano Veloso, presente no disco Amor de Índio, de 1978); Cruzada (Tavinho Moura e Márcio Borges, presente no disco Sol de Primavera, de 1979). Alguns desses exemplos apresentam ênfase na polirritmia e outros nas métricas mistas. É importante salientar que não há uma regra geral, pois observou-se que são diversas as formas de ocorrência dessas interações rítmicas no repertório do grupo, não existindo uma fórmula-padrão. Por vezes elas ocorrem pela sobreposição de dois ou mais elementos de ordem circular e assimétricos em instrumentos diferentes, ou pela simultaneidade de compassos mais regulares e lineares, porém deslocados e/ou subdivididos de formas diferentes, entre outras possibilidades.

Foi na perspectiva de trabalhar com o aspecto assimétrico das interações rítmicas de forma mais enfática que se optou por subtrair, de dois em dois compassos, um dos tempos do pulso no arranjo de Chovendo na Roseira. Na versão original os compassos seguem de forma regular, em fórmula de três tempos, com exceção dos compassos 27 e 34 (conforme Fig. 13), em que a fórmula é alterada para dois tempos. Decidiu-se fazer o oposto no arranjo, ou seja, nos trechos em que os compassos estão regulares na versão original, o arranjo alterna entre compassos de dois e três tempos. Nos trechos em que ocorre alternância de compassos na versão original, o arranjo mantém os compassos regulares em três tempos. Seria possível simplesmente escrever o arranjo em compasso de cinco tempos, porém optou-se por manter a alternância de compassos de três e dois tempos para deixar mais evidente onde ocorre a "subtração" de um dos tempos e onde não ocorre.

A textura vocal é explorada a partir das interações rítmicas e melódicas sugeridas por esses elementos. Combinam-se uníssonos, aberturas em bloco, contracantos de caráter ativo e notas pedais. Relações intervalares de segundas entre as linhas e cruzamentos de vozes também são trabalhados em alguns trechos.

A estrutura formal é praticamente a mesma, com algumas poucas diferenças em relação à versão de 1970. São elas, basicamente: a criação de uma pequena introdução e a expansão da coda, que ficou um pouco maior com o retorno, nos últimos compassos, dos materiais apresentados na introdução. Assim, a estrutura geral do arranjo ficou como ilustrado na Fig. 16. 


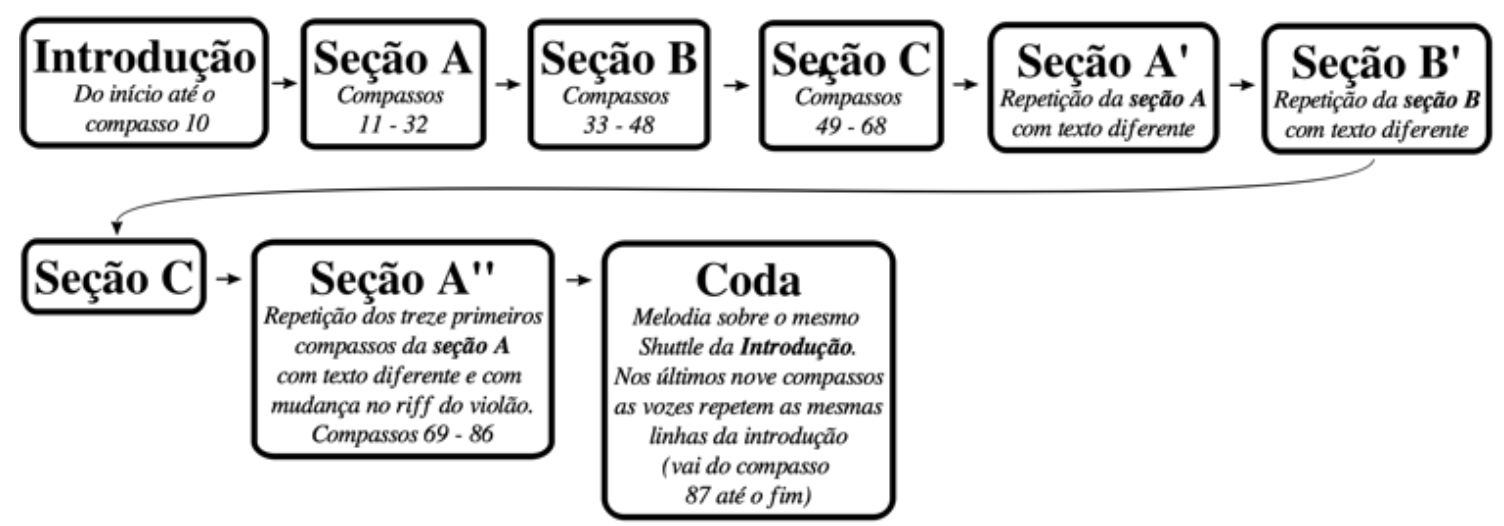

Fig. 16: Estrutura formal do arranjo vocal da canção Chovendo na Roseira

Na versão original, a introdução e a seção A são estruturadas, em termos harmônicos, basicamente pelo shuttle ${ }^{11} \|: \mathrm{Ab}^{(6,9)}(\mathbf{( 6 )} \mid \mathrm{Ebm} 7 / \mathrm{Ab}(\mathrm{Vm} 7 /$ pedal de tônica no baixo) :\|. $\mathrm{O}$ segundo acorde (Ebm7/Ab) pode ser interpretado tanto como $\mathrm{Vm} 7 /$ pedal de tônica no baixo, quanto bVII/9o no baixo (Gb/Ab) ou como 17sus4 $4^{\left({ }^{9)}\right.}$ (Ab7sus4 ${ }^{(9)}$ ). Em qualquer uma dessas interpretações, esse acorde cumpre a função de acorde primário ${ }^{12}$ do modo de lá bemol mixolídio, ou seja, é um shuttle modal característico do ambiente harmônico mixolídio. São os mesmos dois acordes que iniciam a canção Pai Grande, de Milton Nascimento (1969), porém, nesse caso, está em sol mixolídio (conforme Fig. 17).

\section{Pai Grande}

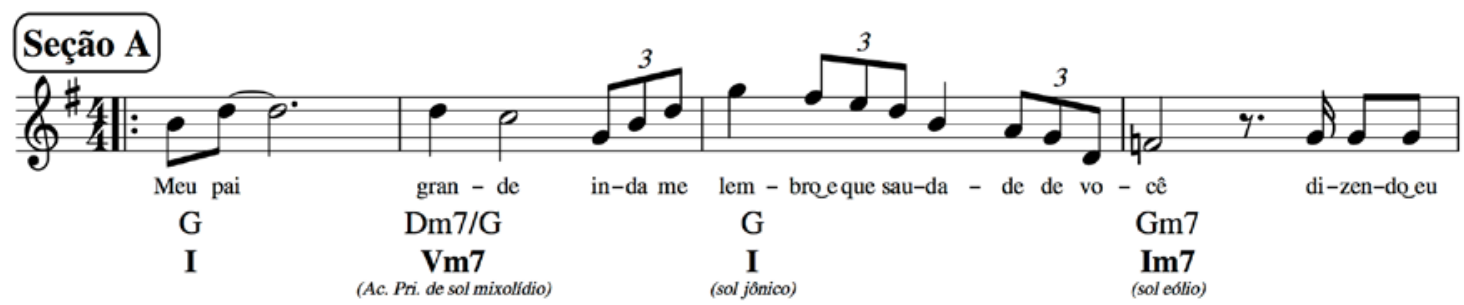

Fig. 17: Acordes iniciais da canção Pai Grande, de Milton Nascimento

No arranjo vocal, este mesmo shuttle é utilizado, porém sem o baixo pedal, dando ênfase ao movimento bVII $\leftrightarrow$ I. Criou-se um riff no violão (Fig. 18) combinando esse shuttle com a ideia de métricas misturadas e com a ideia de explorar notas que cum-

\footnotetext{
11 Tagg (2014) utiliza o termo Shuttle para designar a alternância entre dois acordes. 0 termo Chord Loops é utilizado para a sequência de três ou quatro acordes que se repetem. Os termos Turnaround e Vamp também são utilizados por Tagg (2014), porém como Chord Loops específico. O Turnaround voltado para descrever as sequências de acordes com função de sinalizar o final de um ciclo harmônico que levará a progressão em direção ao começo de outro (TAGG, 2014, p.402), e o Vamp para classe de loops baseados na famosa sequência VIm-IIm-V-I e todas as suas variações (TAGG, 2014, p.404).

12 Segundo Persichetti (2012), em cada campo harmônico modal, os acordes do I grau e os que contêm a nota característica do respectivo modo são chamados de acordes primários, pois cumprem uma certa função de caracterizar o "sabor modal" específico. Os acordes que não contêm essa nota são chamados de acordes secundários.
} 
prem a função de elementos pedais, que nesse caso são as notas mi e si na região médio-agudo do instrumento.

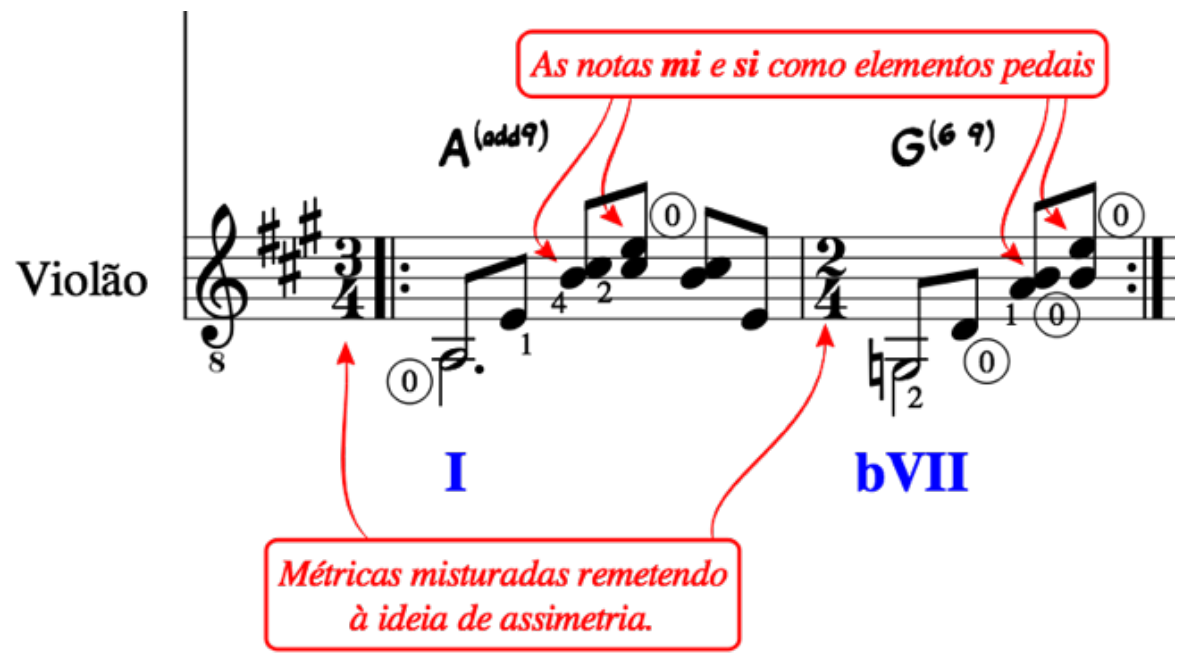

Fig. 18: Riff do violão no arranjo da canção Chovendo na Roseira

O termo elemento pedal está sendo usado aqui para designar um tipo de recurso de utilização de notas pedais que aparece no repertório estudado de modo bastante diversificado, conectado a procedimentos tanto no âmbito modal quanto tonal. Observou-se que ele aparece em trechos das criações musicais do Clube da Esquina como recurso de exploração textural e de enriquecimento de sonoridades no que se refere à construção dos acordes. É comum, por exemplo, a utilização de uma ou mais cordas soltas do violão (seja na região grave, média ou aguda) como elemento fixo enquanto os acordes vão se movimentado. A nota (ou notas) dessa corda solta vai sendo incorporada aos acordes, mesmo quando ela não "pertence" a eles (ou seja, mesmo quando não é nenhuma das notas estruturais presente na escala do acorde). Com isso, os coloridos harmônicos multiplicam-se, pois a nota pedal acaba cumprindo função tanto de caráter vertical (seja como nota da estrutura básica, nota de tensão ou mesmo nota "evitada") quanto horizontal. Sendo assim, ela pode ser interpretada como elemento-guia que conecta e "costura" uma sequência de acordes ao mesmo tempo em que os tensionam. É o elemento fixo contrapondo-se aos elementos móveis, gerando contrastes. Por isso adotou-se na presente pesquisa o termo elemento pedal, ao invés de simplesmente chamar de baixo pedal ou notas pedais, pois é um elemento de constituição do caráter estilístico do grupo, utilizado de forma variada e em contextos diversos, não se limitando ao uso comumente descrito nos livros tradicionais de teoria. Algumas das "harmonias peculiares" atribuídas ao Clube da Esquina vêm desse recurso composicional, como o interlúdio da canção Amigo, Amiga, de Milton Nascimento e Ronaldo Bastos (Fig. 19), e a seção B da canção Dona Olímpia, de Toninho Horta e Ronaldo Bastos (Fig. 20). Tal recurso foi explorado no presente arranjo da canção Chovendo na Roseira por essa perspectiva. 


\section{Amigo, Amiga}

Disco:Milton (1970)

de Milton Nascimento

Faixa 2

- Voz, violão: Milton Nascimento
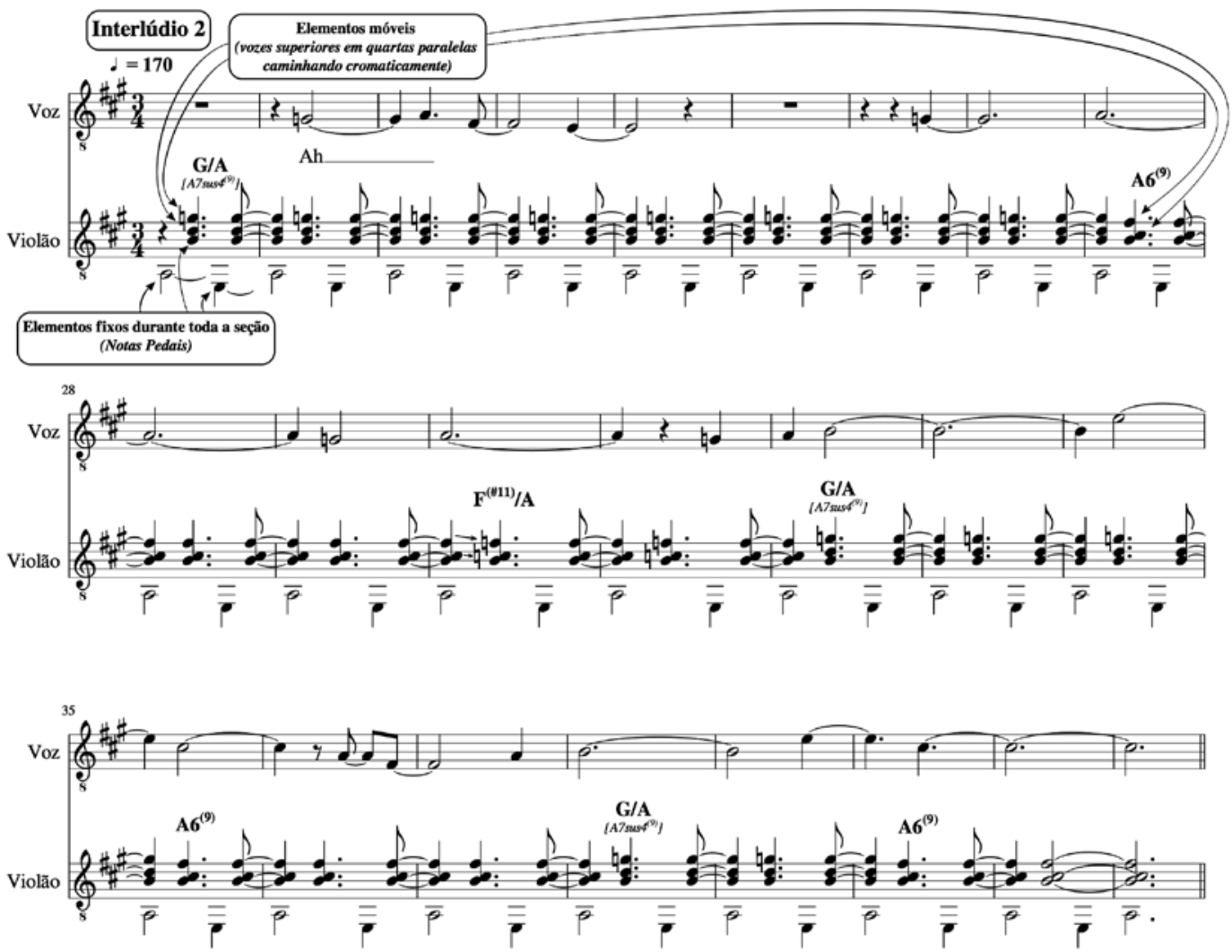

Fig. 19: Trecho do Interlúdio 2 da música Amigo, Amiga, de Milton Nascimento e Ronaldo Bastos (disco Milton, de 1970 - faixa 2)

Disco:Terra dos Pássaros (1979) de Toninho Horta

Faixa 3

Voz, violão: Toninho Horta

\section{Dona Olímpia}

Toninho Horta e Ronaldo Bastos

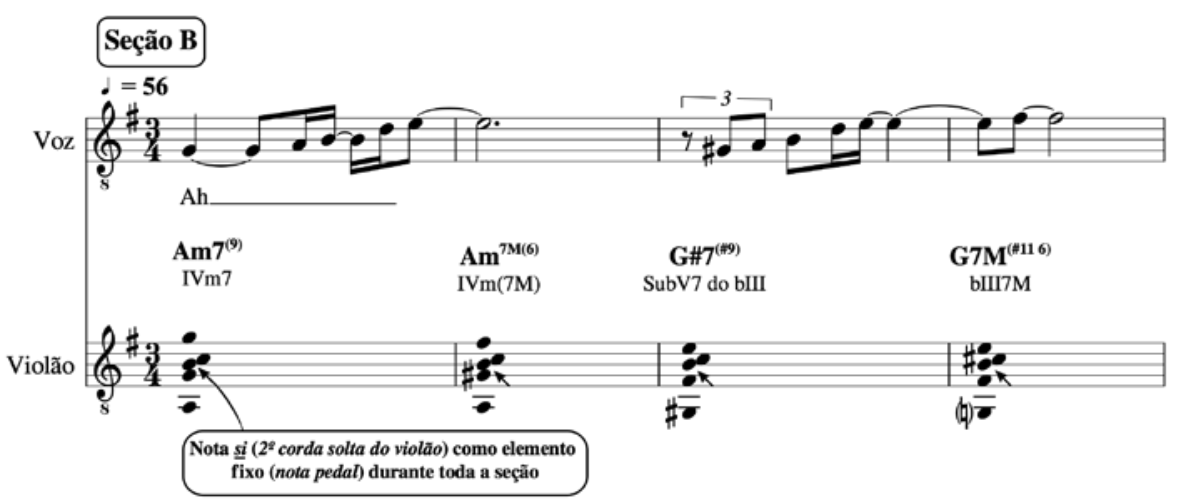




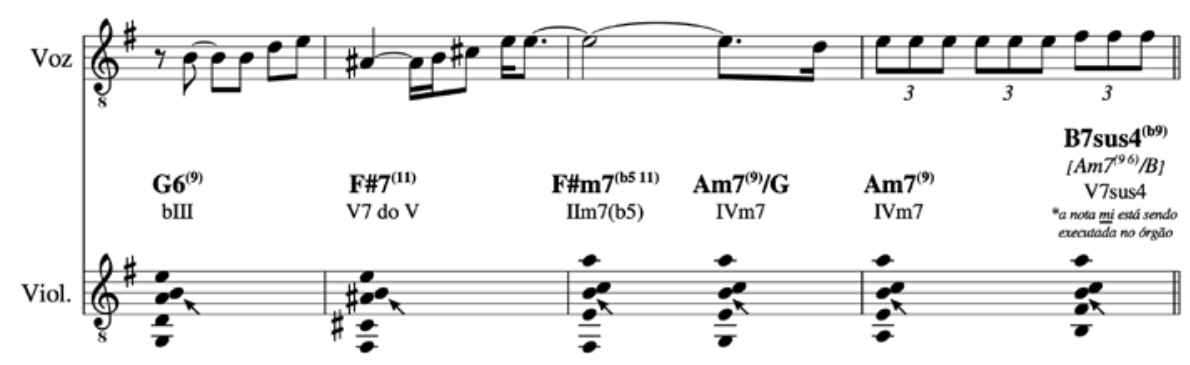

Fig. 20: Seção B da música Dona Olímpia, de Toninho Horta e Ronaldo Bastos (disco Terra dos Pássaros, de 1979 - faixa 3)

Um dos tratamentos texturais mais explorados ao longo do arranjo, no que se refere à escrita das vozes, foi a alternância entre uníssonos e aberturas em bloco, que por vezes se desdobram em contracantos de caráter ativo ou passivo. As linhas vocais criadas na introdução (Fig. 21) sintetizam essa ideia. As vozes começam em uníssono. A partir do compasso 5, abrem-se em duas vozes em bloco (a voz 2 e 3 permanecem em uníssono). No compasso 6 as duas vozes graves executam um trecho um pouco mais ornamentado, voltando à ideia de bloco no compasso 7, que passa a apresentar abertura a três vozes, permanecendo com essa textura até o final da introdução. Movimentos contrários e oblíquos foram bastante explorados nesse trecho do arranjo. A nona maior dos acordes aparece de forma recorrente nos blocos a três vozes.
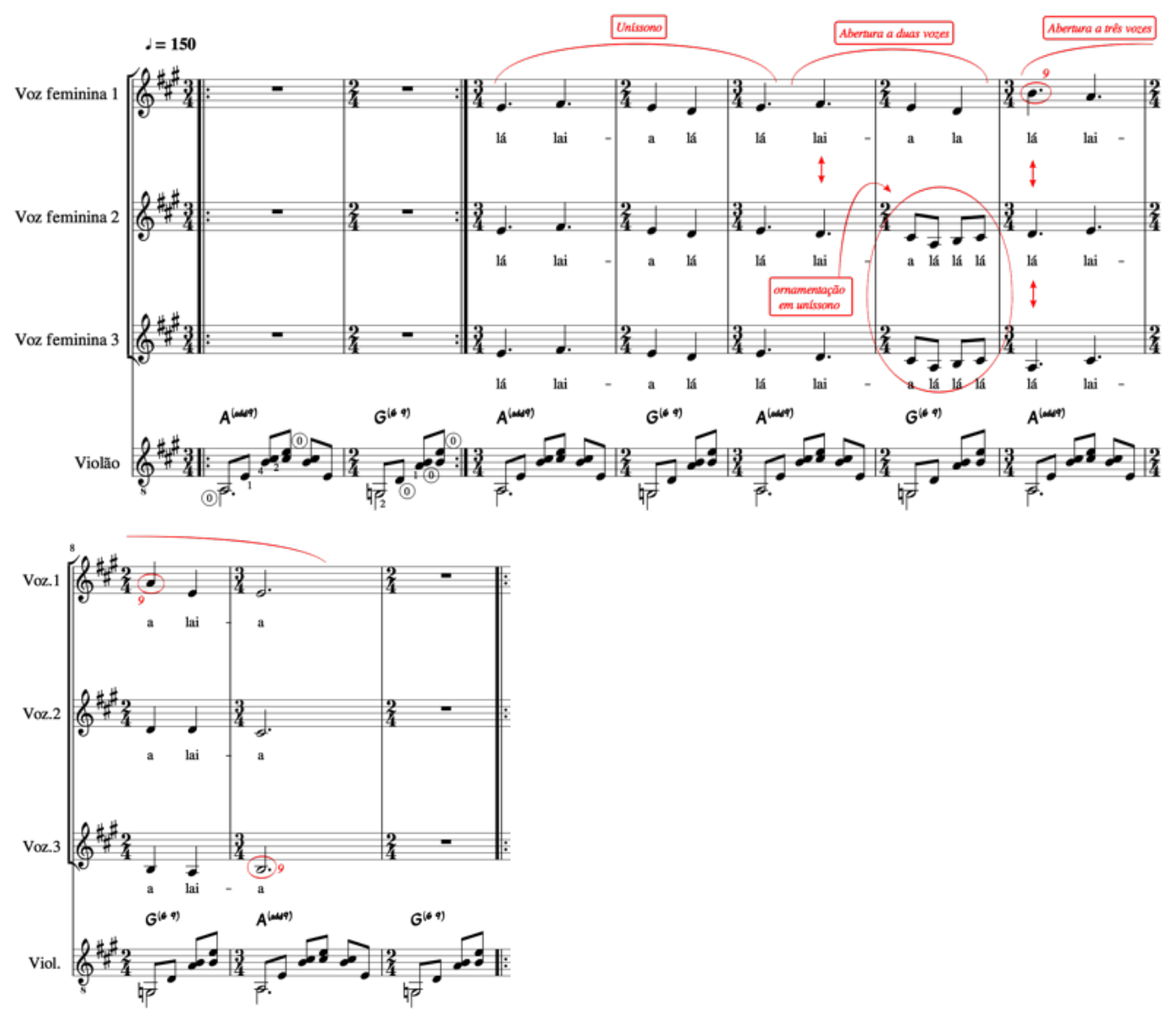

Fig. 21: Introdução do arranjo vocal de Chovendo na Roseira 
Na seção A, as vozes 1 e 2 cantam a melodia principal em uníssono enquanto a voz 3 executa um contracanto de caráter ativo estruturado a partir das linhas melódicas apresentadas na introdução. Essa estrutura segue até o compasso 19. No compasso 20 ocorre uma inversão, as vozes 2 e 3 cantam a melodia principal em uníssono enquanto a voz 1 sustenta a nota mi 3, cumprindo a função de elemento pedal por quatro compassos. A partir do compasso 24, a textura trabalhada é de escrita em bloco na posição cerrada, porém sem seguir os procedimentos tradicionais das técnicas mecânicas, visando explorar de forma um pouco mais intensa os movimentos contrários e oblíquos. Nesse trecho utiliza-se novamente a ideia de começar em uníssono e terminar com abertura a três vozes. Na parte final da seção A (a partir do compasso 27), os compassos ficam simétricos, sem alternância entre 3/4 e 2/4. A harmonia dos quatro últimos compassos dessa seção (do 29 ao 32) foi modificada. Ao invés dos acordes || F\#7sus4 | Em6/F\# | $A^{(6,9)} \mid$ Em7/A || da versão original (já transpostos para a mesma tonalidade do arranjo),

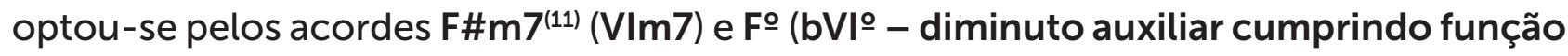
de passagem cromática entre o F\#m7 e o Em7).

Na seção B, a textura trabalhada foi a de escrita em bloco a três vozes com prevalência de movimentos diretos e paralelos. O tratamento rítmico sofre algumas alterações. Durante a execução das frases melódicas, os compassos permanecem em 3/4. Não ocorre a alternância entre 3/4 e 2/4 explorada nas seções anteriores nem a passagem por um compasso 2/4 que aparece na versão original (compasso 27 do manuscrito). A alternância entre 3/4 e 2/4 só volta a aparecer no final das frases. $O$ ritmo melódico da segunda metade das frases se expande, resultando na inserção de um compasso a mais. A melodia principal caminha entre as três vozes conforme indicado na partitura (compassos 35 ao 38 e 43 ao 46). A rearmonização também é explorada nessa seção, de acordo com a Fig. 22.

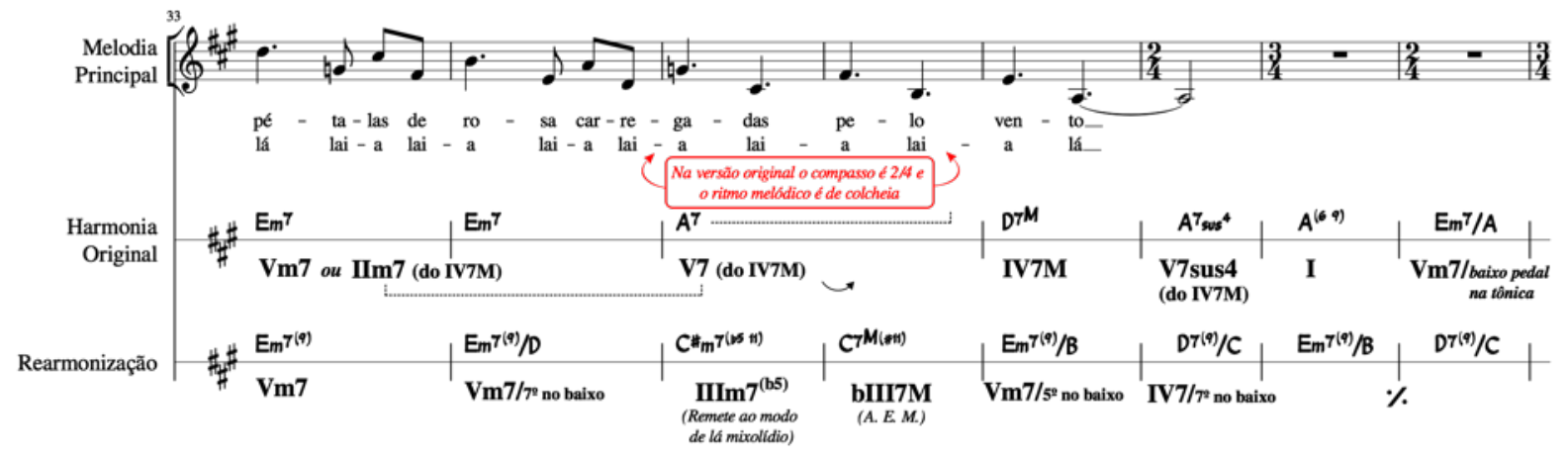




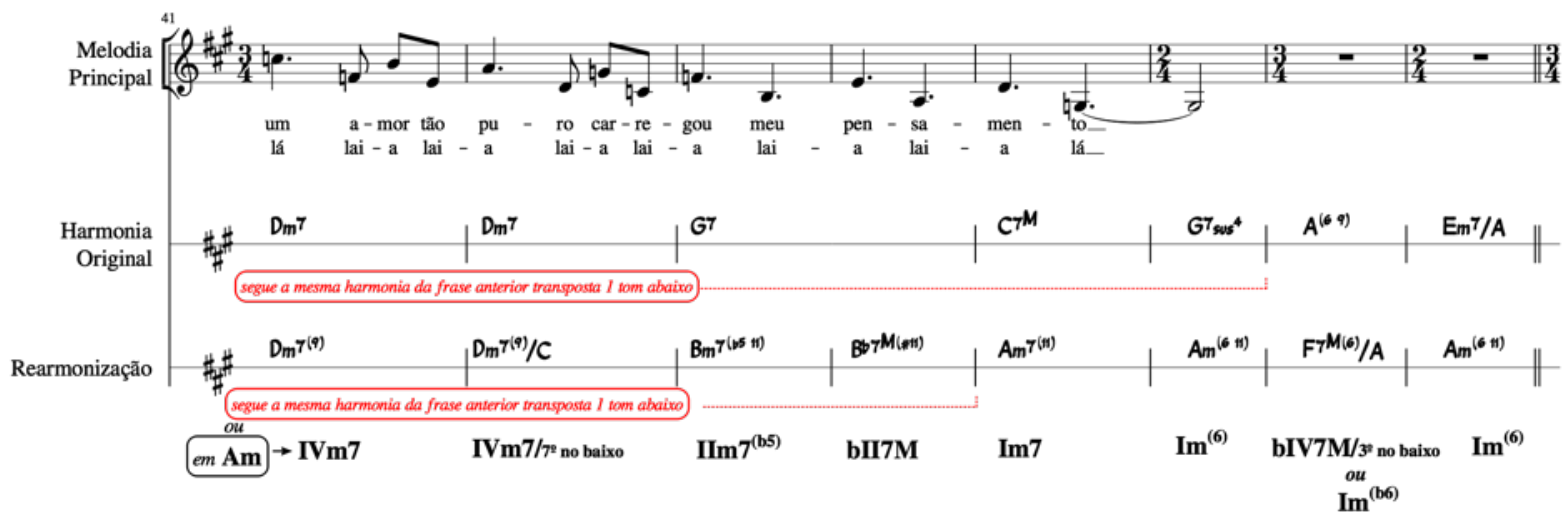

Fig. 22: Rearmonização da seção B do arranjo vocal de Chovendo na Roseira

Ao longo dessa seção, a 1a corda solta do violão (mi 3) e é utilizada como elemento pedal, ou seja, fica soando o tempo todo (Fig. 23).

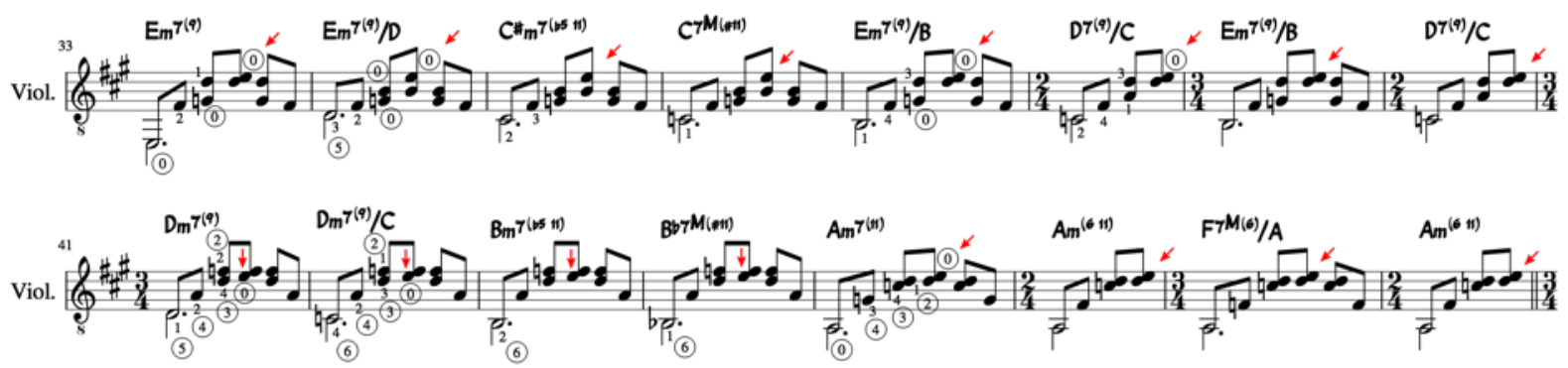

Fig. 23: Violão da seção B do arranjo vocal de Chovendo na Roseira com indicação da $1^{\text {a }}$ corda solta cumprindo a função de elemento pedal

Na seção C, a melodia principal encontra-se estruturada integralmente no modo de si frígio. Na versão original, a harmonia é desenvolvida sobre um baixo pedal em si com acordes provenientes da mistura de vários modos. Um contracanto cromático descendente de caráter passivo presente na linha interna da harmonia (que vai da nota mi até fá\#) norteia, em certa medida, a própria sequência dos acordes (esse contracanto é comumente utilizado em vários arranjos, inclusive na versão de 1974, no disco Elis e Tom). No arranjo vocal, optou-se por rearmonizar toda essa seção. Buscou-se enfatizar o "sabor" frígio. Assim, apenas acordes diatônicos do modo de si frígio foram utilizados (com exceção dos dois últimos compassos). Basicamente, a harmonia gira em torno de

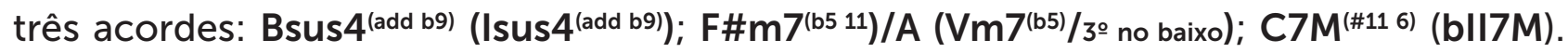
A utilização do acorde de primeiro grau com a quarta suspensa, sem a sétima e com a nona menor, é pouco usual para demarcar a sonoridade modal de si frígio, assim como a utilização do acorde com a quinta diminuta, porém tanto os acordes de tipologia Xsus4 quanto $\mathrm{Xm7}^{\left(\mathrm{b}^{(\mathrm{s})}\right.}$ são amplamente utilizados no repertório do Clube da Esquina, mesmo em ambientes harmônicos modais. Nenhum desses três acordes (Bsus4(add b9), $\left.\mathrm{F} \# \mathrm{~m} \mathbf{7}^{(\mathrm{b5} 11)} / \mathrm{A}, \mathrm{C7M}^{(\# 116)}\right)$ contém a nota ré, que é a terça menor da escala de si frígio. Essa nota aparece apenas no meio da seção, a partir do compasso 55, como nota melódica. A ausência do ré no início da seção gera, em um primeiro momento, um ambiente harmônico menos afirmativo em relação ao modo frígio, que se dissipa quando a nota 
ré natural aparece na melodia. A Figura 24 apresenta a comparação entre a harmonia original e a rearmonização.

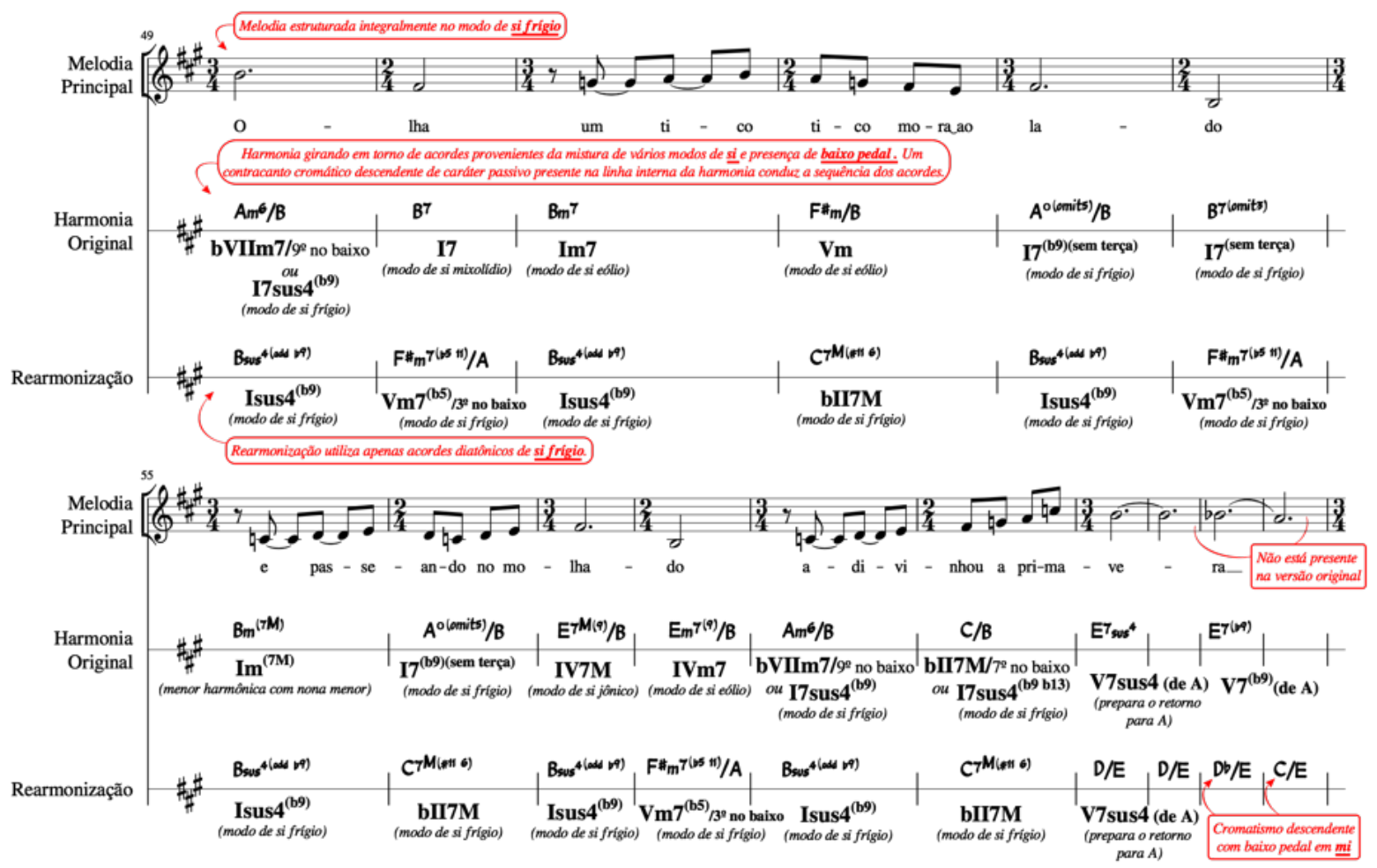

Fig. 24: Harmonia original e rearmonização da seção C do arranjo vocal da canção Chovendo na Roseira

No final dessa seção, utilizou-se o acorde E7sus4 ${ }^{(9)}$ como preparação para o retorno ao acorde de $A^{\text {(add 9) }}$, porém, diferentemente da harmonia original, explorou-se a ideia de manter o baixo em mi e deslocar cromaticamente de forma descendente a tríade de D contida no interior do E7sus ${ }^{(9)}$, procedimento também visto em algumas músicas do Clube da Esquina.

A ideia de utilizar corda solta do violão como elemento pedal também é explorada nessa seção. Dos compassos 49 ao 60, a 1aㅡ e a 2aㅡ cordas soltas (notas mi3 e si2, respectivamente) cumprem a função de elementos pedais. Nos compassos 61 ao 64, a 1a e a 6a cordas (notas mi3 e mi1, respectivamente) cumprem essa função (Fig. 25).

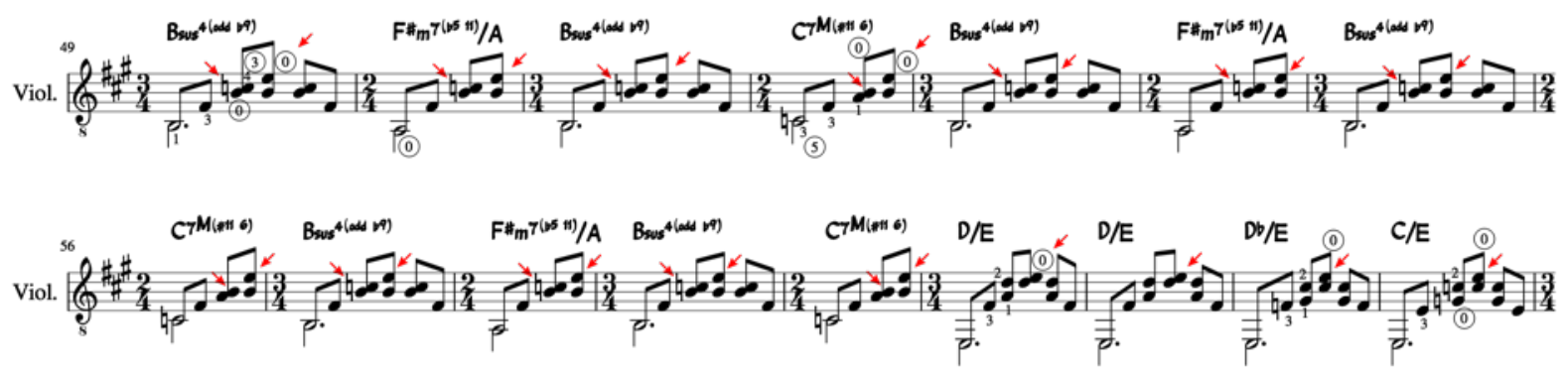

Fig. 25: Violão da seção C do arranjo vocal de Chovendo na Roseira com indicação das cordas soltas que estão cumprindo a função de elemento pedal

Quanto à textura trabalhada nas vozes, essa seção apresenta uma combinação de escrita em bloco com contracanto de caráter ativo. Na escrita em bloco, a voz 1 fixa-se 
na nota mi3 durante os compassos 51 ao 58 , cumprindo também a função de elemento pedal, enquanto a voz 2 canta a melodia principal. Como resultado, surgem intervalos de segundas e cruzamentos de vozes. A partir do compasso 59, todas as vozes cantam em bloco, começando em uníssono e terminando com abertura a três vozes, seguindo a mesma ideia já explorada nas outras seções (Fig. 26).
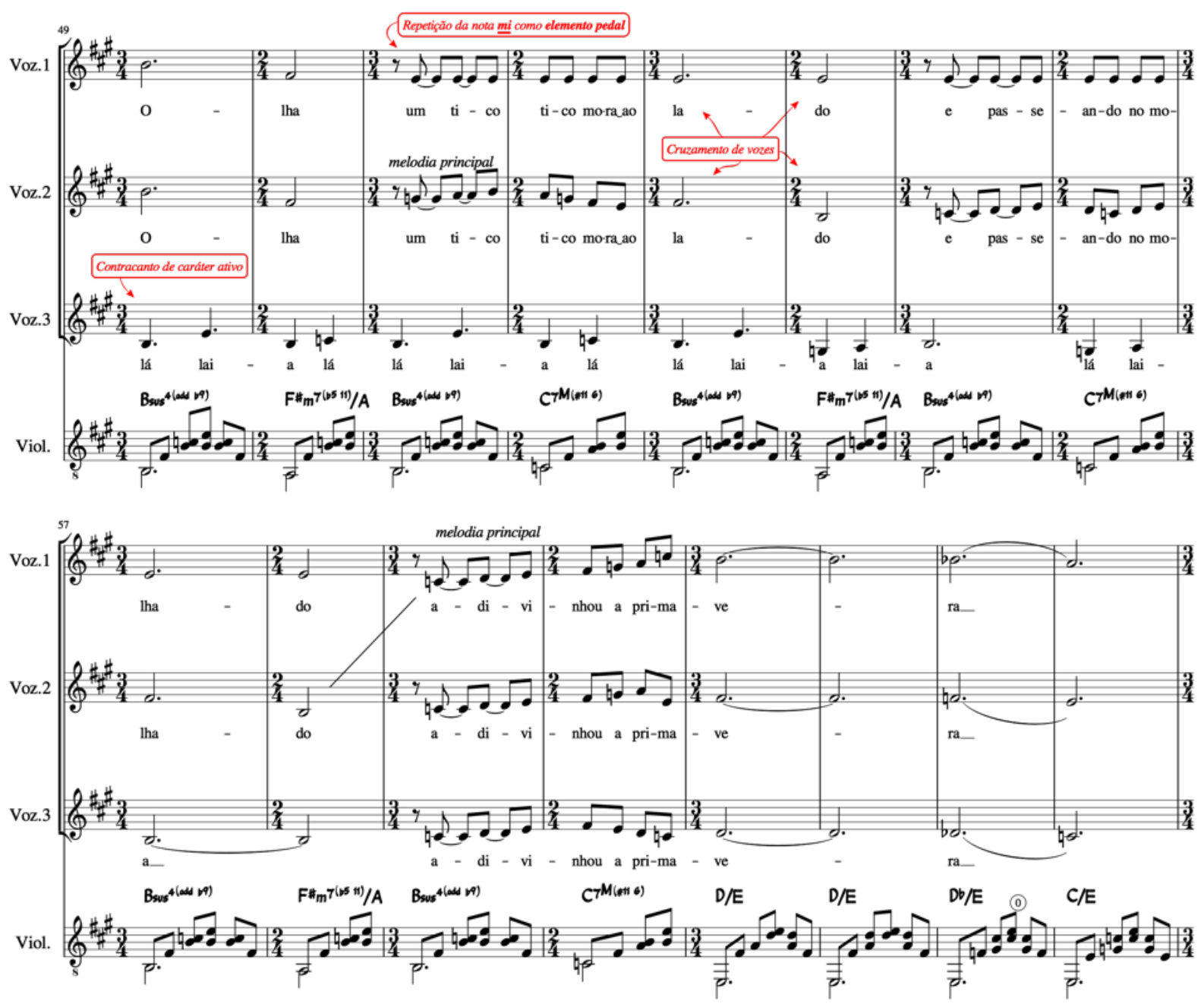

Fig. 26: Seção C do arranjo vocal de Chovendo na Roseira

Depois de repetir praticamente todas as seções, porém com texto diferente, o arranjo caminha para sua conclusão. O riff do violão é modificado. O shuttle $\|: \mathbf{A b}^{(6,9)}$ | Ebm7/ Ab:\| deixa de ser arpejado e passa a ser executado como acordes em bloco até o final, conforme indicado na partitura a partir do compasso 69. As vozes voltam a repetir praticamente as mesmas linhas dos primeiros quatorze compassos da seção $\mathrm{A}$, porém com outra letra. A coda, que começa a partir do compasso 87, apresenta a frase "Ah! Você é de ninguém", que fica se repetindo. Porém, em cada repetição, cada uma das vozes deixa de cantar essa frase e volta para sua respectiva linha da introdução, resultando, depois de três repetições, em um retorno ao mesmo tema apresentado no início do arranjo.

A ideia de trabalhar essa canção por um viés modal era algo que já existia antes do presente estudo, porém durante muito tempo foi sendo adiada. Ao longo da pesquisa, 
percebeu-se que os elementos composicionais que estavam sendo estudados ajudariam a retomar a ideia de explorá-la com ênfase no modalismo. As métricas misturadas, o "elemento pedal" e os demais recursos expostos acima serviram como ferramentas nesse processo de exploração. A seção $C$, construída quase que integralmente sobre o modo frígio, é onde essa ideia fica mais evidente. O contexto modal foi o "solo" sobre o qual foi construído esse arranjo da roseira.

\section{Considerações finais}

A pesquisa integrou duas linhas de investigação: uma com foco no Clube da Esquina, em uma perspectiva analítica/estilística, e a outra com foco nos processos de criação de arranjos vocais. O estudo estilístico do Clube da Esquina revelou-se como uma espécie de compilação de vários procedimentos composicionais provenientes de culturas musicais diversas, que balizaram a prática da música popular urbana na década de 1970 e final da década de 1960. Apesar de o Clube da Esquina não ser o "inventor" de tais elementos, percebe-se, a partir das análises, que ele os combinou de forma particular, ressignificando-os em um contexto cultural próprio. Utilizando a ideia de Continuum Criativo proposta por Nascimento (2011) e transpondo-a do âmbito de concriação ${ }^{13}$ da "obra" na música popular para o âmbito de concriação das práticas e procedimentos composicionais, pudemos observar que essa reelaboração de tais procedimentos presente no trabalho do Clube da Esquina também se situa como concriadora, ou seja, contribuiu para o processo de reinvenção de práticas composicionais já existentes, para as transformações contínuas que permeiam os "modos" de se criar música, no caso, dentro do contexto cultural da música popular no Brasil.

Resgatando as reflexões apresentadas por Molina (2014) de que a sofisticação rítmica da música popular no Brasil reside justamente na fricção constante de dois diferentes princípios rítmicos, um de ordem circular e assimétrico (ligado às práticas modais da música africana) e o outro de ordem linear e simétrico (ligado à música de concerto europeia de caráter tonal), os dados levantados durante o processo analítico nos permitem expandir tais reflexões para o trato composicional do Clube da Esquina de uma forma geral, ou seja, essa fricção constante revela-se também no tratamento harmônico, melódico, timbrístico e formal. A sofisticação dos procedimentos composicionais do grupo assenta-se justamente no amadurecimento dessas fricções. $O$ hibridismo tonal/modal, o "elemento pedal", as polirritmias, o uso recorrente do Vm7 e bll, o uso diversificado do acorde sus4, as seções fortemente contrastantes, os cromatismos, entre outros elementos elencados, desvelam quão relevante foi para a constituição das características estilísticas do Clube da Esquina esse "friccionamento" entre tradições modais e a tradição tonal. Tudo isso é recombinado e inserido em um contexto de pro-

13 Hermilson Nascimento (2011) propõe os termos Coletivo Autoral, Rede Interpoética e Continuum Criativo para explicar o processo de criação e recepção na prática da música popular. A Rede Interpoética e o Continuum Criativo são constituídos pela prática de concriação da obra a partir dos vários arranjos e interpretações que vão surgindo em torno de uma peça ao longo do tempo e do caráter essencialmente aberto da composição popular, permitindo continuidade de criação. Assim, ele achou mais adequado utilizar o termo "concriação" em vez de "cocriação" para falar sobre esses processos. 
dução fonográfica na "era da obra de arte montável" (MOLINA, 2014, p.14) subsidiada pelas novas tecnologias de gravação e manipulação sonora, assim como a efetivação do álbum como gênero complexo do discurso musical.

A pesquisa desses elementos como recursos criativos para elaboração de arranjos vocais possibilitou um processo de experimentações que resultaram em sonoridades mais diversificadas e em uma paleta maior de opções para a escrita de tais arranjos.

Todas essas experimentações se inter-relacionam. Foram trabalhadas de forma integrada no processo de criação dos arranjos, conectando-se aos elementos composicionais utilizados pelo Clube da Esquina.

Utilizando a ideia explorada por Molina (2014) de conceber a articulação dos parâmetros musicais em dois níveis, o nível primário e o nível secundário, ${ }^{14}$ observou-se, ao longo do trabalho de elaboração dos arranjos vocais, que esses elementos empregados pelo Clube da Esquina contribuíram tanto para a exploração composicional no nível primário quanto no secundário. Assim, ajudou a explorar tanto a trama das notas/ acordes e interações rítmicas quanto a trama das texturas, timbres e estrutura formal, visando articular sonoridades mais variadas.

É possível vislumbrar, a partir de tudo que foi exposto, que o processo de criação de arranjos vocais vai muito além de aplicar técnicas de escritas. É, antes, um processo de concepção e reutilização de tudo que se apreende acerca das combinações dos elementos composicionais que nos cercam e que assimilamos de forma consciente ou não. É engendrar sonoridades a partir dos "saberes e fazeres" absorvidos ao longo de nossas experiências com as diversas culturas musicais, que de alguma forma retornam recompiladas, norteando nossa própria poética, subsidiando nosso próprio processo de expressão artística por meio da trama sonora. Os conteúdos abordados aqui apresentam-se, em certa medida, como mais um compartilhamento de experiências, nesse caso, a partir das vivências de cunho estético diante do repertório do Clube da Esquina e de cunho poético frente aos arranjos vocais. Inserir-se nessa grande rede de compartilhamento que constitui o nosso ofício em suas mais diversas práticas é a base de nosso crescimento como músicos e como agentes culturais e sociais.

\footnotetext{
14 Molina (2014) aborda a análise musical em dois niveis de articulação dos parâmetros estruturais, denominados de nível primário e nível secundário. No primeiro, em suma, o foco está na trama dos elementos no nivel de notas, encadeamentos harmônicos, articulações motívicas, variações e desenvolvimento dos temas, enlace dos elementos rítmicos, micro e macroestrutura formal, entre outros parâmetros comumente utilizados no estudo do repertório europeu clássico-romântico e demais composições que, em maior ou menor grau, se conectam a esse paradigma. No nível secundário, o foco está na composição das sonoridades, no qual a trama dos sons é mais importante do que a trama das notas, em que o centro composicional está voltado mais para a dimensão do objeto sonoro, no qual a manipulação das texturas, densidades, âmbitos, intensidades etc. é mais valorizada do que a escolha dessa ou daquela nota musical específica.
} 


\section{Referências}

ACERVO DIGITAL CHIQUINHA GONZAGA. Disponível em: http://www. chiquinhagonzaga.com/acervo/. Acesso em: 1 set. 2015.

ALMADA, C. Arranjo. Campinas: Ed. Unicamp, 2000.

AMARAL, Chico. A música de Milton Nascimento. Belo Horizonte: Gomes, 2013.

BAIA, S F. A historiografia da música popular no Brasil (1971-1999). 2010. 279 f. Tese (Doutorado em História Social) - Faculdade de Filosofia, Letras e Ciências Humanas, Universidade de São Paulo, São Paulo, 2010.

BORGES, Márcio. Os sonhos não envelhecem: histórias do Clube da Esquina. 7. ed. São Paulo: Geração, 2011.

CANÇADO, Wilson Lopes. Novena, Crença e Gira Girou de Milton Nascimento e Márcio Borges: análise de suas três primeiras composições criadas em uma noite de 1964. 2010. 146 f. Dissertação (Mestrado em Música) - Universidade Federal de Minas Gerais, Belo Horizonte, 2010.

CANTON, Ciro Augusto Pereira. Nuvem no céu e raiz: romantismo revolucionário e mineiridade em Milton Nascimento e no Clube da Esquina (1970-1983). 2010. $171 \mathrm{f}$. Dissertação (Mestrado em História) - UFSJ, São João del-Rei, 2010.

CHEDIAK, Almir. Harmonia e improvisação. Rio de Janeiro: Lumiar, 1986.

CORRÊA, Luiz Otávio. Clube da Esquina e Belo Horizonte: romantismo revolucionário numa cidade de formação ambígua. Dissertação (Mestrado em História) - Pontifícia Universidade Católica de Minas Gerais, Belo Horizonte, 2002.

DINIZ, S. C. "Nuvem Cigana": a trajetória do Clube da Esquina no campo da MPB. 2012. 231 f. Dissertação (Mestrado em Sociologia) - Universidade Estadual de Campinas, Campinas, 2012.

DOLORES, Maria. Travessia: a vida de Milton Nascimento. Rio de Janeiro: Record, 2006.

FREITAS, Sérgio P. R. Teoria da Harmonia na Música Popular: uma definição das relações de combinação entre os acordes na harmonia tonal. 1995. 174 f. Dissertação (Mestrado em Música) - Universidade Estadual Paulista, São Paulo, 1995. 
FREITAS, Sérgio P. R. Dos modos em seus mundos: usos do termo modal na teoria musical. In: CONGRESSO DA ASSOCIAÇÃO NACIONAL DE PESQUISA E PÓSGRADUAÇÃO EM MÚSICA, 18., 2008, Salvador. Anais [...]. Salvador, 2008. p. 450-457.

FREITAS, Sérgio P. R. Que acorde ponho aqui? Harmonia, práticas teóricas e o estudo de planos tonais em música popular. 817 f. Tese (Doutorado em Música) Universidade Estadual de Campinas, Campinas, 2010.

GARCIA, Luiz Henrique Assis. Coisas que ficaram muito tempo por dizer: o Clube da Esquina como formação cultural. 2000. 154 f. Dissertação (Mestrado em História) Universidade Federal de Minas Gerais, Belo Horizonte, 2000.

GARCIA, Luiz Henrique Assis. Na esquina do mundo: trocas culturais na música popular brasileira através da obra do Clube da Esquina (1960-1980). 2006. $281 \mathrm{f}$. Tese (Doutorado em História) - Faculdade de Filosofia e Ciências Humanas, Universidade Federal de Minas Gerais, Belo Horizonte, 2006.

GUEST, I. Arranjo: método prático. Rio de Janeiro: Lumiar, 1996. v. 1, 2 e 3.

INSTITUTO ANTÔNIO CARLOS JOBIM. Disponível em: http://www.jobim.org. Acesso em: 1 mar. 2016.

MARTINS, Bruno Viveiros. Som imaginário: a reinvenção da cidade nas canções do Clube da Esquina. Belo Horizonte: Ed. UFMG, 2009.

MENEZES JÚNIOR, C. R. F. Os elementos composicionais do Clube da Esquina como alimentadores de processos criativos de arranjos vocais de canções populares brasileiras. 2016. 562 f. Tese (Doutorado em Música) - Escola de Comunicações e Artes, Universidade de São Paulo, São Paulo, 2016. Disponível em: https://teses.usp.br/ teses/disponiveis/27/27158/tde-05052017-114221/pt-br.php.

MOLINA, S. A composição de música popular cantada: a construção de sonoridades e a montagem dos álbuns no pós-década de 1960. 2014. 152 f. Tese (Doutorado em Música) - Escola de Comunicações e Artes, Universidade de São Paulo, São Paulo, 2014.

MOREIRA, Maria Beatriz Cyrino. Fusões de gêneros e estilos na produção musical da banda Som Imaginário. 2011. 266 f. Dissertação (Mestrado em Música) - Universidade Estadual de Campinas, Campinas, 2011.

NASCIMENTO, H. G. Recriatura de Cyro Pereira: arranjo e interpoética na música popular. 2011. 239 f. Tese (Doutorado em Música) - Instituto de Artes, Universidade Estadual de Campinas, Campinas, 2011. 
NICODEMO, Thais Lima. Terra dos pássaros: uma abordagem sobre as composições de Toninho Horta. 2009. 215 f. Dissertação (Mestrado em Música) - Universidade Estadual de Campinas, Campinas, 2009.

NUNES, Thais G. A. A sonoridade específica do Clube da Esquina. 2005. 175 f. Dissertação (Mestrado em Música) û Instituto de Artes, Universidade Estadual de Campinas, Campinas, 2005.

NUNES, Thais G. A. A voz de Milton Nascimento em presença. 2015. 96 f. Tese (Doutorado em Música) - Instituto de Artes, Universidade Estadual de Campinas, Campinas, 2015.

OLIVEIRA, Rodrigo Francisco. Mil tons de Minas: Milton Nascimento e o Clube da Esquina - cultura, resistência e mineiridade na música popular brasileira. 2006. 134 f. Dissertação (Mestrado em História) - Universidade Federal de Uberlândia, Uberlândia, 2006.

PERSICHETTI, Vincent. Harmonia no século XX: aspectos criativos e prática. Trad. Dorotea Kerr. São Paulo: Via Lettera, 2012.

RAMOS, M. A. da S. O ensino da Regência Coral. 2003. 107 f. Tese (Livre-Docência) Escola de Comunicações e Artes, Universidade de São Paulo, São Paulo, 2003.

RODRIGUES, Mauro. O modal na música de Milton Nascimento. 2000. Dissertação (Mestrado em Musicologia) - Conservatório Brasileiro de Música do Rio de Janeiro, Rio de Janeiro, 2000.

SBERNI JUNIOR, Cleber. O álbum na indústria fonográfica: contracultura e o Clube da Esquina em 1972. Dissertação (Mestrado em História) - Unesp, Franca, 2007.

SILVA, Carlos Alberto Silva da. A negritude através de Maria Maria de Milton Nascimento. 2003. Dissertação (Mestrado em Literatura) - Universidade Federal de Santa Catarina, Florianópolis, 2003.

SOUZA, Alberto Carlos de. Minas e Geraes: um recorte na cultura e na história através de Milton Nascimento. 2010. Dissertação (Mestrado em História) - Universidade Salgado de Oliveira, Niterói, 2010.

STARLING, Heloísa. Coração americano: panfletos e canções do Clube da Esquina. In: REIS, Daniel Aarão; RIDENTI, Marcelo; MOTTA, Rodrigo Patto Sá (org.). O golpe e a ditadura militar: 40 anos depois (1964-2004). São Paulo: Edusc, 2004.

TAGG, Philip. Everyday Tonality II: towards a tonal theory of what most people hear. New York; Huddersfield: The Mass Media Scholar's Press, 2014. 
TEDESCO, Cybelle Angélique Ribeiro. De Minas, mundo: a imagem poético-musical do Clube da Esquina. 2000. 210 f. Dissertação (Mestrado em Multimeios) - Universidade Estadual de Campinas, Campinas, 2000.

VIEIRA, Francisco Carlos Soares Fernandes. Pelas esquinas dos anos 70: utopia e poesia no Clube da Esquina. 1998. 132 f. Dissertação (Mestrado em Poética) - Universidade Federal do Rio de Janeiro, Rio de Janeiro, 1998.

VILELA, Ivan. Nada ficou como antes. Revista USP, dossiê música brasileira, São Paulo, n. 87, p. 14-27, 2010.

VITENTI, Ada Dias Pinto. Uma certa musicalidade nas esquinas de Minas (1960-1970). 2010. 130 f. Dissertação (Mestrado em História) - Universidade de Brasília, Brasília, 2010.

WILLIAMS, R. Marxismo e literatura. Rio de Janeiro: Zahar, 1979.

WILLIAMS, R. Cultura. Rio de Janeiro: Paz e Terra, 1992. 